\title{
Institutional pressure, ultimate ownership, and corporate carbon reduction engagement: evidence from China
}

Article

Accepted Version

Wang, F., Sun, J. and Liu, Y. S. (2019) Institutional pressure, ultimate ownership, and corporate carbon reduction engagement: evidence from China. Journal of Business Research, 104. pp. 14-26. ISSN 0148-2963 doi: https://doi.org/10.1016/j.jbusres.2019.07.003 Available at https://centaur.reading.ac.uk/84194/

It is advisable to refer to the publisher's version if you intend to cite from the work. See Guidance on citing.

To link to this article DOI: http://dx.doi.org/10.1016/j.jbusres.2019.07.003

Publisher: Elsevier

All outputs in CentAUR are protected by Intellectual Property Rights law, including copyright law. Copyright and IPR is retained by the creators or other copyright holders. Terms and conditions for use of this material are defined in the End User Agreement.

www.reading.ac.uk/centaur 
Central Archive at the University of Reading

Reading's research outputs online 


\title{
Institutional pressure, ultimate ownership, and corporate carbon reduction engagement: Evidence from China
}

\begin{abstract}
This paper investigates the relationship between institutional pressure and corporate carbon reduction engagement, as well as the moderating effect of ultimate ownership in China. Using a sample of 2511 firms that were listed on the Shanghai and Shenzhen Stock Exchanges in 2014 and 2015, we find that institutional pressure arising from government evaluation has a positive influence on corporate carbon reduction engagement. Moreover, the positive effect is stronger for non-state-owned enterprises (NSOEs) than for state-owned enterprises (SOEs). The subsequent analysis shows that carbon reduction engagement in NSOEs is positively associated with firms' access to state-owned bank loans. We further observe that there is a momentum of carbon reduction engagement due to institutional pressure. Our findings shed light on how institutional pressure influences firms' decision to engage in carbon reduction and the effectiveness of the carbon reduction policy in China.
\end{abstract}

Keywords: Institutional pressure; Ultimate ownership; Carbon reduction engagement; Financial incentive. 


\section{Introduction}

Scientific evidence for climate change and the heat-trapping nature of carbon dioxide and other gases is unequivocal. For the first time, all nations came to a unanimous decision to undertake collective efforts to combat climate change at the 2015 Paris Climate Summit, and 170 Parties have ratified the Paris Agreement Convention so far. Since the US pulled out of this Convention in June 2017, China has been taking a leading role in the global climate action and ecological civilization endeavor. In the past twenty years, China has achieved an average annual gross domestic product (GDP) growth rate of $10 \%$ and had the second largest GDP in the world in 2015. However, this rapid economic growth has jeopardized the environmental conditions in China, and China replaced the United States as the world's largest carbon emitter in 2009. As a result, the Chinese government is determined to improve the environmental conditions and to transform from a capital-intensive and industrydominated economy to a more sustainable one with a particular focus on fulfilling its international responsibility to tackle climate change issues and to reduce carbon emissions. Therefore, it is interesting to study how the Chinese government has promoted its low-carbon economy and the Chinese firms' responses to these initiatives.

In China, both the central and local governments prioritized economic development over environmental concerns until the eleventh Five-Year Plan. This Plan, however, only provided a general statement on controlling climate change without specifying the actual targets or performance measures. In the twelfth Five-Year Plan, unprecedented attention was given to climate change issues, and specific targets and comprehensive measures were introduced. However, this system did not noticeably alter the local officials' political incentives to engage in carbon abatement (Sun, 2018). In addition, the policies were poorly implemented and were distorted by the local officials due to unreasonable configurations of the objectives and the imperfect statistical system (Lo, 2014). In the thirteenth Five-Year Plan, the Chinese 
government further listed climate change mitigation and carbon emission reductions as one of the five focuses of its agenda. This reflects the great determination of the central government to tackle climate change issues. More importantly, since 2014, the central government has designated the National Development and Reform Commission (NDRC), a powerful authority in China, to evaluate the progress on regional carbon reductions. The evaluation can then be used as an explicit reference in the appointment, promotion, and rotation of local government officials. According to the coercive isomorphism of institutional theory (DiMaggio \& Powell, 1983), the evaluation scheme is expected to exert incremental institutional pressure on local governments and firms and, as a result, a balance between sustainable economic development and continuous climate change improvements has to be achieved. Institutional pressure refers to the force that is exerted on firms within the same field to constrain organizational choices and ensure organizational conformity (Colwell \& Joshi, 2013). This study takes advantage of this unique institutional dynamic to investigate firms' responses to the institutional pressures that are caused by the carbon evaluation mechanism.

While more attention has been paid to institutional pressure as an important driving force of corporate carbon reduction engagement (Baboukardos, 2017; de Aguiar \& Bebbington, 2014; Herold, Farr-Wharton, Lee, \& Groschopf, 2018; Herold \& Lee, 2019; Lan, 2017; Luo, Lan, \& Tang, 2012; Niedertscheider, Haas, \& Görg, 2018; Sadler, 2016; Tang, 2018), the findings of previous studies have yielded mixed results. For instance, some studies find that institutional pressure has a positive influence on corporate carbon reduction engagement (e.g., Herold et al., 2018; Herold \& Lee, 2019; Tang, 2018), while others reveal that the influence is insignificant (e.g., Lo, 2014; Sun, 2018). Moreover, firms respond heterogeneously to institutional pressure (Colwell \& Joshi, 2013; Fikru, 2014), and corporate carbon reduction disclosures and performance vary extensively between firms when they are 
subject to a homogeneous level of institutional pressure (Lan, 2017). Thus, it is necessary to empirically investigate the potential factors that drive firms' heterogeneous responses to institutional pressure.

Previous studies demonstrate how firm size, competitive position and the degree of internationalization moderate institutional pressure on firms' environmental engagement (Sadler, 2016), but the understanding of how ultimate ownership affects this relationship remains limited. In China, firms' ultimate ownership is an important schema for reflecting corporate traits that affect cognition and behavior. Ultimate ownership refers to the identity of the largest shareholder, that is, the ultimate owner (La Porta, Lopez-de-Silanes, \& Shleifer, 1999; Ruiqi, Wang, Xu, \& Yuan, 2017). State-owned enterprises (SOEs) are assets of government, and their ultimate owners belong to the government or government-controlled institutions (Ruiqi et al., 2017). SOEs are therefore perceived not simply as business entities but also as affiliations of the government. Prior studies evidence the existence of regulatory discrimination between SOEs and non-state-owned enterprises (NSOEs) (Wei \& Wang, 1997; Yen \& Abosag, 2016), which is exacerbated by the variation in the economic and legal institutions across different provinces in China (Kusnadi, Yang, \& Zhou, 2015). Nevertheless, this linkage does not exempt firms from institutional pressure; instead, it changes the nature of firms' responsiveness to the pressure (Cui \& Jiang, 2012).

This study focuses on the impact of institutional pressure and ultimate ownership on corporate carbon reduction engagement in the Chinese setting. Some existing studies provide evidence on binding regulations and mandatory policies concerning firms' social and environmental engagement (Andrew \& Cortese, 2011; Baboukardos, 2017), while in China, the issue of environmental policy is mainly in the form of notifications and it, essentially, lacks authority (Liao, 2018). Zhao (2012) highlights the importance of nonregulatory statebusiness interactions for understanding the dynamics of corporate social and environmental 
responsibilities. The author calls for further studies on the institution-organization linkage to understand the nature of firms' social and environmental responsibilities beyond mere legal compliance. Our study responds to this call by investigating the association between the Chinese government's carbon evaluation scheme and corporate carbon reduction engagement. In particular, we advance the existing literature by offering a political perspective on whether the ultimate ownership influences firms' carbon reduction decisions in response to institutional pressure.

We examine a sample of Chinese listed firms from 2014 to 2015, during which the central government delegated the NDRC to evaluate the local carbon reduction performance. We employ carbon reduction reporting and carbon reduction performance as the two measures of corporate carbon reduction engagement. After controlling for other determinants that were used in the existing literature, our results show that institutional pressure arising from the evaluation scheme has been effective at promoting firms' engagement in carbon reduction. Consistent with an institutional and political view of legitimacy, NSOEs are more responsive than SOEs to such institutional pressure. Further tests reveal that the carbon reduction engagement of NSOEs has a significant impact on firms' access to state-owned bank loans while no significant impact is found for government subsidies. This partly explains why NSOEs are more responsive to government initiatives.

The contributions of this paper are threefold. First, our research identifies the motivational role of institutional pressure on firms' carbon reduction engagement in China, which complements the existing evidence on the determinants of carbon reduction engagement (Ben-Amar, Chang, \& McIlkenny, 2017; Ben-Amar, McIlkenny, \& Comyns, 2015; Liao, Luo, \& Tang, 2015). Current literature on the role of the government in promoting corporate carbon reduction engagement often focus on the institutional pressure from formal regulatory frameworks and policies (Andrew \& Cortese, 2011; Baboukardos, 
2017), the institutional pressure that is perceived by firms (Lan, 2017; Tang, 2018), and the institutional pressure from government initiatives in developed economies (Liu \& Yang, 2018; Tauringana \& Chithambo, 2015). For developing economies such as China, businesses tend to prioritize profits and growth over social and environmental responsibilities, and thus mandatory interventions from the government are deemed to be essential (Lo, 2014; Sun, 2018). Indeed, Lo (2014) and Sun (2018) report that the Chinese government's energyconservation target responsibility system has not noticeably changed the local governments' incentives to reduce carbon emissions. However, our findings show that the introduction of the evaluation and monitoring mechanism has imposed a stronger incentive for firms to engage in carbon reduction activities.

Second, this study advances the understanding of the influence of ultimate ownership on firms' carbon reduction decisions from a political perspective. Some institutional scholars suggest that coercive pressure results in industry and firm-level heterogeneity rather than isomorphism (Clemens \& Douglas, 2006; Hoffman, 1999). Our findings highlight the importance of ultimate ownership in explaining firms' heterogeneous responsiveness to the institutional pressure, e.g., NSOEs are more responsive than SOEs. Prior research has examined the institutional mechanism in which firms are independent of institutions (Colwell \& Joshi, 2013; Fikru, 2014; Herold \& Lee, 2019; Tingey-Holyoak, 2014), but very few studies have examined the institutional process when firms are naturally connected to the institutions (Cui \& Jiang, 2012; Lan, 2017; Tang, 2018). Our study provides a unique setting to empirically examine firms' heterogeneous responses to homogenous pressure.

Third, we provide important insights into the financial incentives motivating firms to engage in government's carbon reduction policies. According to the China Banking Regulatory Commission, firms with carbon reduction engagement could benefit from concessional loans at relatively lower interest rates. Our further analysis on firms' access to 
state-owned bank loans further substantiates the existence of financial incentives that underlie the influence of institutional pressure on firms' carbon reduction engagement. Government financial support is an effective incentive to motivate firms to strike a balance between their financial performance and their social and environmental responsibilities.

The remainder of this paper is organized as follows. Section 2 reviews the related literature and develops the research hypotheses. Section 3 presents the research methodology. Section 4 discusses the empirical results and the conclusion follows in Section 5.

\section{Literature Review and Hypotheses Development}

\subsection{Institutional pressure and carbon reduction engagement}

Institutional theory is concerned with the relationship between the organization and its environment and recognizes the influence of the environment on organizational structures and processes (DiMaggio \& Powell, 1983; Scott, 2006). While the efficiency incentive is not sufficient to explain why organizations are becoming more homogeneous, institutional theory posits that organizations incorporate social and institutional beliefs in order to maintain their stability and legitimacy in society rather than to achieve organizational efficiency (DiMaggio \& Powell, 1983; Meyer \& Rowan, 1977). Institutional theory, therefore, asserts that the external environment and the institutions create pressure for an adaptation cycle and lead to homogeneity in organizational structures and practices, where isomorphism best captures the homogenization process among organizations (DiMaggio \& Powell, 1983). DiMaggio and Powell (1983) argue that coercive forces, as well as normative and mimetic forces, force organizations to adopt specific strategies. Coercive refers to the ways in which organizations are coerced into a course of actions as a result of both formal and informal pressures that exerted on the organization by other institutions. Institutions that are able to enforce such changes in organizations are usually powerful constituents, e.g., the government, certification bodies or powerful stakeholders. 
Institutional theory has been applied to the study of corporate responsiveness to environmental issues. For example, institutional pressure is found to be an important determinant of corporate carbon reduction performance (Lan, 2017; Niedertscheider et al., 2018) and carbon reduction disclosures (Baboukardos, 2017; de Aguiar \& Bebbington, 2014; Lan, 2017; Luo et al., 2012; Sadler, 2016; Tang, 2018). Other studies find that corporate environmental management decisions are reactions to multiple internal and external pressures that coexist and are coconstructed with institutional pressure (Herold et al., 2018; Herold \& Lee, 2019; Rothenberg, 2007). In addition, institutional pressure also influences the association between corporate carbon emission disclosure and carbon emission performance (Luo, 2017). However, the empirical results of institutional pressure on firms' environmental engagement are not conclusive. Lo (2014) and Sun (2018) conclude that the institutional pressure from the energy conservation scheme in China has an insignificant influence on local officials' incentives to engage in carbon reduction.

Indeed, the Chinese central government launched energy conservation on a nationwide scale in 2005 and introduced energy conservation into the target responsibility system to evaluate local governments in 2006. This initiative, before the introduction of the NDRC evaluation, was overshadowed by economic targets and did not promote the convergence of per capita $\mathrm{CO}_{2}$ emissions (Sun, 2018). Since 2014, the Chinese central government has delegated the NDRC as a powerful authority to evaluate and publish regional carbon reduction progress and the results would constitute an explicit reference in the appointment, promotion, and rotation of local government officials, which is a typical reflection of a regionally decentralized authoritarian regime (RDAR). China has been characterized as an RDAR country $(\mathrm{Xu}, 2011)$. The RDAR features highly centralized political and personnel controls at the national level, and a regionally decentralized administrative and economic system $(\mathrm{Xu}, 2011)$. Despite the extensive autonomy of the local governments, the central 
government retains the ultimate power to appoint, promote, and rotate local officials, which serves as a powerful incentive for local officials to follow the central government's policies.

As a transitional economy and RDAR, the Chinese government intervenes in economic and social activities not only through regulations and taxation but also through channels such as enforcement, licenses, quotas, permits, and franchise assignments (Lee, Walker, \& Zeng, 2017; Wong, 2016). Although the central government has not directly intervened in carbon reduction, the launch of a regional carbon reduction evaluation scheme could play a vital role in urging local governments and their regional enterprises to engage. According to the coercive isomorphism of institutional theory, firms are coerced into a course of actions as a result of both formal and informal pressures that exerted on the organization by other institutions (DiMaggio \& Powell, 1983). Although the energy conservation initiative is found to have an insignificant influence on carbon abatement in its earlier stage (Lo, 2014; Sun, 2018), we argue that when the central government prioritized carbon reduction in its agenda and appointed the NDRC to monitor the progress, coercive pressure was formed on local governments and firms. This discussion leads to our first hypothesis:

H1 Corporate carbon reduction engagement is positively associated with institutional pressure.

\subsection{Institutional pressure, ultimate ownership and carbon reduction engagement}

Some institutional scholars argue that institutional pressure, particularly coercive pressure, results in industry and firm-level variations in strategies and practices rather than isomorphism (Clemens \& Douglas, 2006; Hoffman, 1999). Firms will consider their current circumstances when making decisions under institutional pressure (Berrone, Fosfuri, Gelabert, \& Gomez-Mejia, 2013). Previous study demonstrates how firm size, competitive position and the degree of internationalization moderate institutional pressure on firms' environmental engagement (Sadler, 2016); however, the understanding of the effect of ultimate ownership 
on such a relationship remains limited. Ultimate ownership affects corporate responsiveness to institutional pressure in the following ways.

First, firms need to proactively secure legitimacy for their long-term growth prospects (Dowling \& Pfeffer, 1975), which is especially vital for NSOEs. With institutional pressure from local government, NSOEs are expected to be more responsive in promptly adopting the government's policies. In contrast, when facing institutional dynamics, SOEs have very limited legitimacy threats due to government protection. As such, NSOEs are likely to be more responsive to institutional pressure than SOEs.

Second, SOEs, whose ultimate owner is the government, are highly influenced by national policies to assist the government in accomplishing broader political and social goals (Jefferson, 1998). The management of SOEs in China is composed of quasi-government officials who are evaluated by a bureaucratic system that is not necessarily focusing on firms' profitability but rather on carrying out government policy mandates (Dong \& Putterman, 2003). Consequently, SOEs are more likely to actively engage in carbon reduction due to their nature than NSOEs and are not just limited to despondence to institutional pressure. Therefore, the link between institutional pressure and carbon reduction engagement should be weaker in SOEs.

Third, because of being highly connected to the government, SOEs have soft budget constraints and are also entitled to more financial resources than NSOEs (Dong \& Putterman, 2003; Wong, 2016). Generally, SOEs have better access to government-supported resources, which help them to engage in environmental-friendly activities (Lee et al., 2017). NSOEs need to cultivate/maintain connections with the government to acquire better operating environments and financial benefits (Kusnadi et al., 2015; Yen \& Abosag, 2016), such as easier access to the debt market (Herbohn, Gao, \& Clarkson, 2017; Jung, Herbohn, \& Clarkson, 2016) and government subsidies (Lee et al., 2017). The government often uses 
financial policy, such as concessional loans and government subsidies, to inspire firms to conform to the institutional pressure. To gain access to more financial resources, NSOEs are expected to be more sensitive to government carbon reduction initiatives than SOEs.

From these perspectives, we argue that NSOEs' carbon reduction engagement is more correlated with institutional pressure than that of SOEs'. Based on the above arguments, we posit our second hypothesis as follows:

H2 The positive relationship between institutional pressure and corporate carbon reduction engagement is more pronounced among NSOEs than SOEs.

\section{Research Design}

\subsection{Sample and data}

Our initial sample includes all A-share listed companies in China from 2014 to 2015. We investigate the period from 2014 to 2015 for the following reasons: (1) the evaluation of provincial carbon reductions by the NDRC began in 2014, (2) the evaluation was restructured after 2015 with the start of the next Five-Year Plan in which there are incomparable regional carbon reduction targets (Yuan \& Zuo, 2011), and (3) the data of the regional evaluation results of the Thirteenth Five-Year Plan are not publicly available. We process the sample according to the following criteria: (1) companies in the financial industry are excluded (101 observations), and (2) samples with missing data are excluded (1,305 observations). Our final sample includes 4,663 firm-year observations of 2,511 listed companies. Financial and corporate governance data are obtained from the China Securities Markets and Accounting Research database (CSMAR).

\subsection{Dependent variable: corporate carbon reduction engagement}

Concerning corporate carbon reduction engagement, we consider both carbon reduction reporting and carbon reduction performance. In recent climate change studies, it is consistently accepted that carbon emission performance or carbon emission reporting should 
not be examined alone without considering the other (Matsumura, Prakash, \& Vera-Muñoz, 2014). We therefore employ two measures of carbon reduction engagement: carbon reduction reporting (CRE1) and carbon reduction performance (CRE2).

With regard to CRE1, we follow a qualitative content analysis approach to rate the disclosure quality of firms' annual reports and CSR reports (Qiu, Shaukat, \& Tharyan, 2016; Wiseman, 1982). Each report was hand-reviewed to acquire the detail descriptions of the carbon reduction information. A score of 2 was assigned if quantitative carbon reduction related information was present, a score of 1 was assigned if only qualitative carbon reduction related information is disclosed, and a score of 0 was assigned otherwise.

CRE2 is measured using the Energy Saving Scores from the Hexun.com CSR database. Hexun.com was founded in 1996 and has become one of China's largest financial information portals. Its Social and Environmental Responsibility ratings are designed to evaluate a firm's engagement in the supply chain, employee welfare, shareholder interests, and social and environmental issues, which are widely used in previous research (Han, You, \& Nan, 2019; Li, Zhang, \& Foo, 2013). The Environment Responsibility rating covers five areas: Energy Savings, Types of Pollution, Investment in Environment Protection, the Accreditation of the Environment Management System, and Environmental Consciousness. Energy Savings is one of the most efficient ways for carbon reduction and it can also be implemented in any sector. We therefore employ the energy saving data as a proxy of a firm's carbon reduction performance.

\subsection{Independent variable: institutional pressure}

Institutional pressure $(I P)$ is measured based on the NDRC's evaluation results of the carbon reduction in different regions. Since 2014, the NDRC, on behalf of the Chinese central government, has taken the responsibility to assess and rank the carbon reduction progress of each province. In addition to ranking the provincial carbon reduction performance, 
the NDRC also grades the results into outstanding, good, pass and fail. The results constitute an important reference for the appointment, promotion, and rotation of local government officials. Based on institutional theory, we expect that the evaluation results will create significant institutional pressure for local governments to improve their carbon performance in the following year, and the institutional pressure will be higher for companies with lower grades. We therefore score IP from 1 to 4 according to the evaluation results $(1=$ the evaluation grade is outstanding, and $4=$ the evaluation grade is failing). As a robustness test, we also replace institutional pressure with the ranking in the evaluation result $\left(I P_{-} R\right)$. The details of the evaluation results for the years 2013 and 2014 from the NDRC website are shown in Table 1.

\section{[Insert Table 1 about here]}

\subsection{Moderating variable: ultimate ownership}

We rely on ultimate ownership (SOEs vs NSOEs) as a moderator of the relationship between institutional pressure and carbon reduction engagement. SOE is an indicator variable that equals 1 if the ultimate owner is the government or a government-controlled institution, and it is 0 otherwise (Ruiqi et al., 2017). The information is obtained from CSMAR.

\subsection{Control variables}

Following prior studies (Ioannou, Li, \& Serafeim, 2016; Matsumura et al., 2014; Sadler, 2016), we control for the province- and firm-specific factors in our regression analysis. For the macro province-specific factors, we use regional GDP growth as a proxy for degree of local economic development attention (GDPgrowth) and area distinction to measure regional economic, legal and culture differences (Area). For the firm-specific factors, we control for industries based on the categories that are used in the NDRC's guidelines. The NDRC issues guidelines on the measuring and reporting greenhouse gas emissions, which requests that high pollution industries report their carbon emission data. The industry difference (INDD) is 
coded as one if the industry is classified as a high pollution industry in the NDRC guidelines and zero otherwise. Following Sadler (2016), we also control for market force factors in our model, which include the degree of internationalization (Export) and competitive position (Marketshare). A firm's fixed-asset investment usually requires related environmental assessments, and we control for the increase of fixed assets (Invest) in the model (Ioannou et al., 2016). Corporate governance practices have potential effects on carbon reduction strategies, and, therefore, the institutional shareholding ratio (II), the shareholding ratio of the largest shareholder $(F 1)$, and the total number of directors (Director) are controlled (BenAmar et al., 2017; Dyck, Lins, Roth, \& Wagner, 2019). We further control for firm growth using the book-to-market ratio (BTM) (Matsumura et al., 2014). Finally, we also consider the firms' financial characteristics that affect corporate climate-change strategies, such as firm size (Size), firm leverage (Lev), and firm profitability $(R O A)$ (Clarkson, Li, Richardson, \& Vasvari, 2010). Table 2 presents the detailed descriptions of all the variables in the models.

\section{[Insert Table 2 about here]}

\subsection{Model specification}

To test the effect of institutional pressure on corporate carbon reduction engagement, as well as the moderating effect of ultimate ownership, our regression models are as follows:

$$
\begin{aligned}
& \text { CRE }_{i, t}=\alpha_{0}+\alpha_{1} I_{i, t}+\alpha_{2} \text { SOE }_{i, t}+\alpha_{3} \text { GDPgrowth }_{i, t}+\alpha_{4} \text { Area }_{i, t}+\alpha_{5} \text { INDD }_{i, t}+\alpha_{6} \text { Export }_{i, t}+\alpha_{7} \text { Marketshare }_{i, t} \\
& +\alpha_{8} \text { Invest }_{i, t}+\alpha_{9} I_{i, t}+\alpha_{10} F_{i, t}+\alpha_{11} \text { Director }_{i, t}+\alpha_{12} \text { BTM }_{i, t}+\alpha_{13} \text { Size }_{i, t}+\alpha_{14} \text { Lev }_{i, t}+\alpha_{15} \text { ROA }_{i, t} \\
& +\sum \text { Industry }+\sum \text { Year }+\varepsilon \\
& C R E_{i, t}=\alpha_{0}+\alpha_{1} I P_{i, t}+\alpha_{2} S O E_{i, t}+\alpha_{3} I P_{i, t} * S O E_{i, t}+\alpha_{4} \text { GDPgrowth }_{i, t}+\alpha_{5} \text { Area }_{i, t}+\alpha_{6} I N D D_{i, t}+\alpha_{7} \text { Export }_{i, t} \\
& +\alpha_{8} \text { Marketshare }_{i, t}+\alpha_{9} \text { Invest }_{i, t}+\alpha_{10} I_{i, t}+\alpha_{11} F I_{i, t}+\alpha_{12} \text { Director }_{i, t}+\alpha_{13} \text { BTM }_{i, t}+\alpha_{14} \text { Size }_{i, t} \\
& +\alpha_{15} \text { Lev }_{i, t}+\alpha_{16} \text { ROA }_{i, t}+\sum \text { Industry }+\sum \text { Year }+\varepsilon
\end{aligned}
$$

In all models, $i$ and $t$ denote the firm and year, respectively. We include industry and year fixed effects and use ordinary least squares (OLS) regressions for the estimation. Based on $\mathrm{H} 1$, we expect the coefficient of $I P$ to be significantly positive. To test the moderating effect of ultimate ownership on the relationship between institutional pressure and carbon 
reduction engagement, we add the interaction item between institutional pressure $(I P)$ and ultimate ownership $(S O E)$ in model (2). The coefficient of the interaction item $\left(I P^{*} S O E\right)$ is expected to be significantly negative according to $\mathrm{H} 2$.

\section{Empirical results}

\subsection{Descriptive statistics}

Table 3 presents the descriptive statistics of the sample firms. Firms' engagement in carbon reduction is quite low in terms of both reporting and performance. The average carbon reduction reporting $(C R E 1)$ is only 0.264 while the maximum score that a firm could get is 2 . Regarding the carbon reduction performance (CRE2), the mean is 0.333 with a maximum score of 7 and a minimum of zero. The decisions to disclose carbon information and to reduce carbon emissions are both very low (mean of CRE1_D: 0.171 and mean of $C R E 2 \_D$ : 0.077). Institutional pressure (IP) ranges from 1 to 4 with a mean of 1.228 , which indicates that the pressure for most companies is mild and less dispersed ( $\mathrm{sd}=0.525$ ). The second measure of institutional pressure $\left(I P_{-} R\right)$ using the evaluation ranking for the robustness check ranges from 1 to 31 . The variable $S O E$ averages 0.395 and reflects that $39.5 \%$ of sample firms are SOEs.

\section{[Insert Table 3 about here]}

\subsection{Multivariate analysis}

\section{Institutional pressure and corporate carbon reduction engagement}

Table 4 presents the results of our regression with different measures of carbon reduction engagement and different sets of fixed effects. The results using carbon disclosure measures are presented in columns 4-1 to 4-4 and the results using energy saving measures are presented in columns $4-5$ to $4-8$. IP is significantly positively associated with $C R E 1$ $($ coefficient $=0.031$ and $\mathrm{t}-\mathrm{stat}=2.220$ in column $4-4)$ and $C R E 2($ coefficient $=0.203$ and $\mathrm{t}-$ stat $=3.869$ in column $4-8$ ), which is consistent with our prediction in hypothesis H1. In 
terms of marginal effects, a one unit increase in institutional pressure increases the carbon reduction reporting by 0.031 and the carbon reduction performance by 0.203 , which is economically significant compared with the mean of carbon reduction engagement. Our results indicate that institutional pressure from governmental carbon reduction evaluations is more likely to promote firms' engagement in carbon reduction activities. Moreover, ultimate ownership is also positively associated with firms' carbon reduction reporting (coefficient $=$ 0.114 and $\mathrm{t}$-stat $=5.527$ in column $4-4)$ and carbon reduction performance $($ coefficient $=$ 0.126 and t-stat $=2.242$ in column $4-8$ ), suggesting that SOEs are more active in carbon reduction engagement than NSOEs.

\section{[Insert Table 4 about here]}

\section{Institutional pressure, ultimate ownership and corporate carbon reduction engagement}

Table 5 presents the evidence for hypothesis H2. First, we decompose the full sample into SOEs and NSOEs and separately compare the coefficients of institutional pressure between the two groups. The results show that institutional pressure is significantly and positively associated with a firm's disclosure of carbon information for the NSOE group $(C R E 1$ coefficient $=0.076$ and $\mathrm{t}$-stat $=3.162)$ while the association is insignificant for the SOE group $(C R E 1$ coefficient $=0.003$ and $\mathrm{t}$-stat $=0.126)$. Moreover, the coefficient of carbon reduction performance $(C R E 2)$ is higher for the NSOEs (coefficient $=0.278$ and $\mathrm{t}$-stat $=6.959$ ) than for the SOEs (coefficient $=0.164$ and $\mathrm{t}$-stat $=2.513$ ). For comparison, we use the seemingly unrelated estimation (suest) and conduct a $\chi^{2}$ test to test the differences in the coefficients of $I P$. We find a significant difference for $C R E 1$ and a marginal difference for CRE2. This is preliminarily consistent with hypothesis H2. Second, we apply Model (2) to investigate the interaction effect between institutional pressure and ultimate ownership on corporate carbon reduction engagement. The coefficients of $I P^{*} S O E$ on $C R E 1$ and $C R E 2$ are both significantly negative, suggesting that NSOEs are more responsive to institutional 
pressure than SOEs. The results indicate that the effects of institutional pressure on carbon reduction engagement are distinguishable between SOEs and NSOEs. Our findings support $\mathrm{H} 2$ that the positive association between institutional pressure and carbon reduction engagement is more pronounced for NSOEs than SOEs. From a public policy perspective, our results highlight the importance of nonregulatory state-business interactions beyond legal compliance.

\section{[Insert Table 5 about here]}

\subsection{Further analysis}

\section{Carbon reduction engagement and financial resources}

Having documented that institutional pressure increases firms' carbon reduction reporting and promotes more carbon reduction performance, we try to further substantiate our conjecture that firms' concern over access to different financial resources drives their carbon reduction engagement (Jung et al., 2016; Kusnadi et al., 2015). For example, according to the China Banking Regulatory Commission, firms with carbon reduction engagement could obtain concessional loans at relatively lower interest rates. Concerning financial resources, we focus on concessional loans and subsidies from the government, which are found to be linked with firms' social and environmental related activities in the previous literature (Jung et al., 2016; Lee et al., 2017).

We divide the sample into two groups according to their ultimate ownership: SOEs and NSOEs. Regarding concessional loans, we use whether a firm can obtain loans from a stateowned bank (Loanstate) as a proxy (Firth, Lin, \& Wong, 2008; Sapienza, 2004). As discussed in previous research, state-owned banks charge lower interest rates, impose fewer restrictions on capital expenditures (Firth et al., 2008; Sapienza, 2004), and especially favor SOEs over NSOEs (Wei \& Wang, 1997). Following Sapienza (2004), we code Loanstate as 1 if a firm gets one or more loans from a state-owned bank (Agricultural Bank of China, 
Agricultural Development Bank of China, Bank of China, Bank of Communications, China Construction Bank, China Development Bank, Industrial and Commercial Bank of China, Postal Savings Bank of China, or Export-Import Bank of China), and 0 otherwise. Referring to Lim, Wang \& Zeng (2015) and Minnis (2011), we also include several control variables for the potential effect on Loanstate in model (3), including the area distinction (Area), industry difference (INDD), the book-to-market ratio (BTM), firm size (Size), leverage (Lev), firm profitability $(R O A)$, the shareholding ratio of the largest shareholder $(F 1)$, the tangible asset ratio (TOA), cash flows (CFO), and firm age (Age).

Concerning government subsidies, we focus on corporate carbon related subsidies that are identified from the footnote information in financial statements in the CSMAR database. First, we identify the carbon related subsidies whose account abstracts contain the following key words: 'carbon', 'environment', 'green', 'energy saving', 'clean technology' and 'ecology'. Then, we aggregate the subsidies by firm and year, and get the carbon related subsidies and the total amount of carbon related subsidies. Last, we scale the carbon related subsidies using the total revenue. Following Lim et al. (2015), we also consider a number of factors as possible determinants of subsidies by including the area distinction (Area), the industry difference $(I N D D)$, the book-to-market ratio (BTM), firm size (Size), leverage (Lev), firm profitability $(R O A)$, the shareholding ratio of the largest shareholder $(F 1)$, the firm tax rate (Htax), the earning target (ET) and the carbon related subsidies of the last year (LSubsidy) in model (4).

All the data of above variables is obtained from CSMAR. Industry and year fixed effects are included in all models. The detailed descriptions of the variables' definitions are given in Table 2. Our regression models are as follows:

$$
\begin{aligned}
\text { Loanstate }_{i, t}= & \delta_{0}+\delta_{1} \text { CRE }_{i, t}+\delta_{2} \text { Area }_{i, t}+\delta_{3} I_{N D D_{i, t}}+\delta_{4} \text { BTM }_{i, t}+\delta_{5} \text { Size }_{i, t}+\delta_{6} \text { Lev }_{i, t}+\delta_{7} \text { ROA }_{i, t}+\delta_{8} F 1_{i, t} \\
& +\delta_{9} \text { TOA }_{i, t}+\delta_{10} C F O_{i, t}+\delta_{11} \text { Age }_{i, t}+\sum \text { Industry }+\sum \text { Year }+\varepsilon
\end{aligned}
$$




$$
\begin{aligned}
\text { Subsidy }_{i, t}= & \chi_{0}+\chi_{1} \text { CRE }_{i, t}+\chi_{2} \text { Area }_{i, t}+\chi_{3} \operatorname{INDD}_{i, t}+\chi_{4} \text { BTM }_{i, t}+\chi_{5} \text { Size }_{i, t}+\chi_{6} \text { Lev }_{i, t}+\chi_{7} \text { ROA }_{i, t} \\
& +\chi_{8} F 1_{i, t}+\chi_{9} \text { Htax }_{i, t}+\chi_{10} E T_{i, t}+\chi_{11} \text { LSubsidy }_{i, t}+\sum \text { Industry }+\sum \text { Year }+\varepsilon
\end{aligned}
$$

Table 6 shows that carbon reduction reporting and performance are significantly and positively associated with firms' access to state-owned bank loans for NSOEs (shown in columns 6-2 and 6-6), while the results are insignificant for SOEs. In addition, when using the seemingly unrelated estimation (suest) and conducting a $\chi^{2}$ test to compare the coefficients of $C R E$, we find statistically significant differences between SOEs and NSOEs regarding firms' access to state-owned bank loans. The likelihood of NSOEs' access to stateowned bank loans increases by $15.2 \%$ (which is double the marginal effect of CRE1 on Loanstate, 0.076) and 25.9\% (which is seven times the marginal effect of CRE2 on Loanstate, 0.037), respectively, when CRE1 and CRE2 increase from their minimum to maximum. Government subsidies are not found to be linked with firms' carbon reduction engagement. Overall, the findings substantiate our inference that financial incentives, especially concessional loans, drive NSOEs' responses to government carbon reduction initiatives, which is consistent with the assumption of $\mathrm{H} 2$.

\section{[Insert Table 6 about here]}

\section{Corporate carbon reduction engagement before and after the evaluation}

From the above discussion, we find that the institutional pressure from the evaluation scheme has a positive influence on corporate carbon reduction engagement. While our research design has the advantage of observing the corporate response to institutional pressure in a pure carbon reduction setting, the relatively short time period we examined does not allow us to fully address the heterogeneity across the firms. To enable a comparison of corporate carbon reduction engagement before and after the evaluation was launched, we collected additional data on our sample firms during the years 2012 and 2013 using the same coding approach. To empirically test the difference, we add a period dummy variable (Post) 
in the original models, which equals 1 if the year is 2014 and 2015, and 0 otherwise. We also add the interaction term between institutional pressure $(I P)$ and the period dummy variable (Post), which is expected to have a positive coefficient according to hypothesis H1. The regression statistics are presented in Table 7 and the results are consistent. Particularly, the interaction term $\left(\operatorname{Post}^{*} I P\right)$ is significantly positive, showing that the institutional pressure during the evaluation period can truly enhance corporate carbon engagement after controlling for the potential effect of the evaluation's implementation.

\section{[Insert Table 7 about here]}

\section{Institutional pressure and subsequent corporate carbon reduction engagement}

Corporate carbon reduction engagement may be limited by existing conditions and may be realized in the next few years. We therefore further test the influence of institutional pressure on subsequent corporate carbon reduction engagement. We have collected the data for the year 2016, which is the beginning of the Thirteen Five-Year Plan, and we expect that there is a momentum of corporate carbon reduction under institutional pressure.

Table 8 shows the empirical results. Institutional pressure $\left(I P_{t-1}\right)$ in the year 2015 has a significantly positive effect on corporate carbon reduction reporting and performance in the year 2016, while there is no positive effect of the institutional pressure in the year $2014\left(I P_{t-2}\right)$. The results evidence a momentum of carbon reduction under institutional pressure, which may persist for one year. We also examine the interaction effect of previous institutional pressure and ultimate ownership on corporate carbon reduction engagement and find insignificant results (the coefficients of $I P_{t-1} * S O E_{t}$ and $I P_{t-2} * S O E_{t}$ are both insignificant). This means that NSOEs are more likely to strategically manage their carbon reduction engagement in response to the temporal institutional pressure.

[Insert Table 8 about here] 


\subsection{Robustness check}

\section{Alternative regression model}

Because the dependent variables $C R E 1$ and $C R E 2$ are nonnegative, we use a negative binomial model to test hypotheses $\mathrm{H} 1$ and $\mathrm{H} 2$ for robustness check. The empirical results are shown in Table 9 Panel A. The coefficients of $I P$ are all significantly positive and the interaction item $\left(I P^{*} S O E\right)$ is significantly negative, which is similar to the main results.

\section{Alternative measures of key variables}

As a robustness check, we replicate our tests of hypotheses $\mathrm{H} 1$ and $\mathrm{H} 2$ with alternative measures of our key variables $I P, C R E 1$ and $C R E 2$. We first use the natural logarithm of IP to diminish the variance of the institutional pressure measure. Second, we change the independent variable $(I P)$ to the ranking, which ranges from 1 to $31\left(I P{ }_{-}\right)$. The results that are shown in Panel B (1) and (2) of Table 9 also support our hypotheses H1 and H2.

We further assess the robustness of our measurement choice of corporate carbon reduction engagement. We use dummy variables to measure corporate carbon reduction engagement (CRE1_D and $\left.C R E 2 \_D\right)$ in our model to test hypotheses $\mathrm{H} 1$ and $\mathrm{H} 2$ by applying a logistic regression. We get consistent results, as shown in Table 9 Panel B (3). We also use the dummy variables $C R E 1$ and $C R E 2$ to test the effects of carbon reduction engagement on firms' access to state-owned bank loans and government subsidies. The results that are shown in Table 10 Panel A remain robust.

\section{Alternative sample-excluding NSOEs with political connections}

NSOEs with political connections have informal ties with bureaucrats and can receive unique resources from the government (Wang, Xu, Zhang, \& Shu, 2018). We therefore conduct an additional test to check whether there is any potential endogeneity issue due to the political connections of some NSOEs. We exclude the NSOEs with political connections from our original sample. Following prior research (Feng, Johansson, \& Zhang, 2015; Wang 
et al., 2018), an NSOE is politically connected if the firm's ultimate owner, board member or CEO is the member of the People's Congress or the People's Political Consultative Conference. The results that are shown in Panel C of Table 9 and Panel B of Table 10 are consistent with the main analysis.

\section{[Insert Table 9 and Table 10 about here]}

\subsection{Other endogeneity issues}

To eliminate concerns over the selection bias of engaging in carbon reduction activities, we use the propensity-score matching method to compare the loans and subsides of firms that engage in carbon reduction with a matched sample of firms that are not involved in carbon reduction activities, assuming that selection occurs using observable firm characteristics.

Specifically, following the prior literature (Rosenbaum \& Rubin, 1983), we first use the carbon reduction engagement dummy variables $\left(C R E 1 \_D\right.$ and $\left.C R E 2 \_D\right)$ as independent variables and apply a probit model, which is similar to model (1), to estimate the probability of engaging in carbon reduction activities within the full sample. Next, we calculate the propensity score for each observation based on the above regression and match each engaging firm with non-engaging firms having a caliper distance of 0.1 per year and industry without replacement. Finally, we get 312 observations with carbon reduction reporting, 1323 observations without carbon reduction reporting, 311 observations with carbon reduction performance, and 1318 observations without carbon reduction performance.

We compare the difference of variables in model (3) and model (4) before and after matching. After matching, there is no significant difference between the treated group and the control group in terms of the mean of the dependent variables. From the untabulated results, we can know that there is a significant difference in Loanstate between firms with carbon reduction reporting and firms without $(\mathrm{p}=0.062)$, but after matching, the significant difference is eliminated $(p=0.304)$. In addition, firms' key characteristics, such as firm size, 
leverage, and the book-to-market ratio, are also less selective after matching. Using the matching sample, we get similar results for the effects of carbon reduction engagement on firms' access to bank loans and government subsidies varying among SOEs and NSOEs, which are shown in Table 11.

\section{[Insert Table 11 about here]}

\section{Conclusion}

This study contributes to the growing literature on corporate carbon reduction engagement by examining the impact of institutional pressure arising from the government carbon evaluation scheme, as well as the influence of ultimate ownership on such an impact, in the Chinese setting. Using a sample of Chinese listed firms from 2014 to 2015, we obtain the following original findings. First, we find a significantly positive association between institutional pressure and corporate carbon reduction engagement, which is measured using carbon reduction reporting and carbon reduction performance. Second, we document that the association is stronger for NSOEs than SOEs. These results show that firms' reactions to government evaluation pressure are moderated by the ultimate ownership. Third, we further discover that the carbon reduction engagement of the NSOEs is positively linked with firms' access to state-owned bank loans. Fourth, the empirical results also show that there is a momentum of corporate carbon reduction engagement under the institutional pressure.

From a public policy perspective, our results highlight the importance of nonregulatory state-business interactions beyond legal compliance. Although the carbon reduction engagement in Chinese companies is, overall, rather low, we do find that institutional pressure can play an important role in promoting corporate carbon reduction engagement. In the meantime, the Chinese government should consider providing more financial incentives to firms, especially NSOEs, to engage in such a strategy. The NSOEs in developing countries usually have difficulties accessing bank loans, securing property rights, and enforcing 
contracts (Kusnadi et al., 2015; Yen \& Abosag, 2016). They would therefore have a stronger motivation to closely follow the state strategy to build up and/or strengthen their relationship with the government. Our results are also of great interest to potential investors in Chinese listed firms. Investors would be interested to know that active engagement with government initiatives to reduce carbon emissions is a significant mitigation strategy allowing firms to reduce their financing costs. It could also reflect a decrease in firms' operational and compliance risks. 


\section{References}

Andrew, J., \& Cortese, C. (2011). Accounting for climate change and the self-regulation of carbon disclosures. Accounting Forum, 35(3), 130-138.

https://doi.org/10.1016/j.accfor.2011.06.006

Baboukardos, D. (2017). Market valuation of greenhouse gas emissions under a mandatory reporting regime: Evidence from the UK. Accounting Forum, 41(3), 221-233. https://doi.org/10.1016/j.accfor.2017.02.003

Ben-Amar, W., Chang, M., \& McIlkenny, P. (2017). Board gender diversity and corporate response to sustainability initiatives: Evidence from the Carbon Disclosure Project. Journal of Business Ethics, 142(2), 369-383. https://doi.org/10.1007/s10551-015-2759-1

Ben-Amar, W., McIlkenny, P., \& Comyns, B. (2015). Board Effectiveness and the Voluntary Disclosure of Climate Change Information. Business Strategy and the Environment, 24(8), 704-719. https://doi.org/10.1002/bse.1840

Berrone, P., Fosfuri, A., Gelabert, L., and Gomez-Mejia, L. R. (2013). Necessity as the mother of "green" inventions: Institutional pressures and environmental innovations. Strategic Management Journal, 34(8), 891-909. https://doi.org/10.1002/smj.2041

Clarkson, P. M., Li, Y., Richardson, G. D., and Vasvari, F. P. (2010). Does it really pay to be green? Determinants and Consequences of Proactive Environmental Strategies. Journal of Accounting Public Policy, 30(2), 122-144. https://doi.org/10.1016/j.jaccpubpol.2010.09.013

Clemens, B., \& Douglas, T. J. (2006). Does coercion drive firms to adopt "voluntary" green initiatives? Relationships among coercion, superior firm resources, and voluntary green initiatives. Journal of Business Research, 59(4), 483-491. https://doi.org/10.1016/j.jbusres.2005.09.016

Colwell, S. R., \& Joshi, A. W. (2013). Corporate Ecological Responsiveness: Antecedent Effects of Institutional Pressure and Top Management Commitment and Their Impact on Organizational Performance. Business Strategy and the Environment, 22(2), 73-91. https://doi.org/10.1002/bse.732

Cui, L., \& Jiang, F. (2012). State ownership effect on firms' FDI ownership decisions under institutional pressure: A study of Chinese outward-investing firms. Journal of International Business Studies, 43(3), 264-284. https://doi.org/10.1057/jibs.2012.1

de Aguiar, T. R. S., \& Bebbington, J. (2014). Disclosure on climate change: Analysing the UK ETS effects. Accounting Forum, 38(4), 227-240. https://doi.org/10.1016/j.accfor.2014.10.002

DiMaggio, P. J., \& Powell, W. W. (1983). The iron cage revisited: Institutional isomorphism and collective rationality in organizational fields. American Sociological Review, 48(2), 147-160. https://doi.org/10.2307/2095101

Dong, X. Y., \& Putterman, L. (2003). Soft budget constraints, social burdens, and labor redundancy in China's state industry. Journal of Comparative Economics, 31(1), 110133. https://doi.org/10.1016/S0147-5967(02)00012-4 
Dowling J, \& Pfeffer J. (1975). Organizational legitimacy: social values and organizational behaviour. Pacific Sociological Review, 18(1), 122-136.

https://doi.org/10.2307/1388226

Dyck, A., Lins, K. V., Roth, L., \& Wagner, H. F. (2019). Do institutional investors drive corporate social responsibility? International evidence. Journal of Financial Economics, 131(3), 693-714. https://doi.org/10.1016/j.jfineco.2018.08.013

Feng, X., Johansson, A. C., \& Zhang, T. (2015). Mixing business with politics: Political participation by entrepreneurs in China. Journal of Banking \& Finance, 59, 220-235. https://doi.org/10.1016/j.jbankfin.2015.06.009

Fikru, M. G. (2014). International certification in developing countries: The role of internal and external institutional pressure. Journal of Environmental Management, 144, 286296. https://doi.org/10.1016/j.jenvman.2014.05.030

Firth, M., Lin, C., \& Wong, S. M. (2008). Leverage and investment under a state-owned bank lending environment: Evidence from China. Journal of Corporate Finance, 14(5), 642653. https://doi.org/10.1016/j.jcorpfin.2008.08.002

Han, S., You, W., \& Nan, S. (2019). Zombie firms, external support and corporate environmental responsibility: Evidence from China. Journal of Cleaner Production, 212, 1499-1517. https://doi.org/10.1016/j.jclepro.2018.12.136

Herbohn, K., Gao, R., \& Clarkson, P. M. (2017). Evidence on Whether Banks Consider Carbon Risk in Their Lending Decisions. Journal of Business Ethics, 143(2), 1-19. https://doi.org/10.1007/s10551-017-3711-3

Herold, D. M., \& Lee, K. H. (2019). The influence of internal and external pressures on carbon management practices and disclosure strategies. Australasian Journal of Environmental Management, 26(1), 63-81. https://doi.org/10.1080/14486563.2018.1522604

Herold, D. M., Farr-Wharton, B., Lee, K.-H., \& Groschopf, W. (2018). The interaction between institutional and stakeholder pressures: Advancing a framework for categorising carbon disclosure strategies. Business Strategy \& Development, forthcoming. https://doi.org/10.1002/bsd2.44

Hoffman, A. J. (1999). Institutional evolution and change: Environmentalism and the U.S. chemical industry. Academy of Management Journal, 42(4), 351-371. https://doi.org/10.2307/257008

Ioannou, I., Li, S. X., \& Serafeim, G. (2016). The effect of target difficulty on target completion: The case of reducing carbon emissions. The Accounting Review, 91(5), 1467-1492. https://doi.org/10.2308/accr-51307

Jefferson, G. H. (1998). China's state enterprises: Public goods, externalities, and Coase. American Economic Review, 88(2), 428-432. https://www.jstor.org/stable/116961

Jung, J., Herbohn, K., \& Clarkson, P. M. (2016). Carbon risk, carbon risk awareness and the cost of debt financing. Journal of Business Ethics, 150(4), 1151-1171. https://doi.org/10.1007/s10551-016-3207-6 
Kusnadi, Y., Yang, Z., \& Zhou, Y. (2015). Institutional development, state ownership, and corporate cash holdings: Evidence from China. Journal of Business Research, 68(2), 351-359. https://doi.org/10.1016/j.jbusres.2014.06.023

La Porta, R., Lopez-de-Silanes, F., \& Shleifer, A. (1999). Corporate ownership around the world. Journal of Finance, 54(2), 471-517. https://doi.org/10.1111/0022-1082.00115

Lan, Z. (2017). A study of institutional pressures and dynamic capability and its impact on corporate carbon reduction performance. Retrieved from https://researchdirect.westernsydney.edu.au/islandora/object/uws:46841/

Lee, E., Walker, M., \& Zeng, C. (2017). Do Chinese state subsidies affect voluntary corporate social responsibility disclosure? Journal of Accounting and Public Policy, 36(3), 179-200. https://doi.org/10.1016/j.jaccpubpol.2017.03.004

Li, Y., Zhang, J., \& Foo, C. T. (2013). Towards a theory of social responsibility reporting: empirical analysis of 613 CSR reports by listed corporations in China. Chinese Management Studies, 7(4), 519-534. https://doi.org/10.1108/CMS-09-2013-0167

Liao, L., Luo, L., \& Tang, Q. (2015). Gender diversity, board independence, environmental committee and greenhouse gas disclosure. British Accounting Review, 47(4), 409-424. https://doi.org/10.1016/j.bar.2014.01.002

Liao, Z. (2018). Content analysis of China's environmental policy instruments on promoting firms' environmental innovation. Environmental Science and Policy, 88, 46-51. https://doi.org/10.1016/j.envsci.2018.06.013

Lim, C. Y., Wang, J., \& Zeng, C. C. (2018). China's "mercantilist" government subsidies, the cost of debt and firm performance. Journal of Banking \& Finance, 86, 37-52. https://doi.org/10.1016/j.jbankfin.2017.09.004

Liu, Y. S., \& Yang, J. H. (2018). A longitudinal analysis of corporate greenhouse gas disclosure strategy. Corporate Governance: The International Journal of Business in Society, 18(2), 317-330. https://doi.org/10.1108/CG-11-2016-0213

Lo, K. (2014). China's low-carbon city initiatives: The implementation gap and the limits of the target responsibility system. Habitat International, 42, 236-244. https://doi.org/10.1016/j.habitatint.2014.01.007

Luo, L. (2017). The influence of institutional contexts on the relationship between voluntary carbon disclosure and carbon emission performance. Accounting and Finance, forthcoming. https://doi.org/10.1111/acfi.12267

Luo, L., Lan, Y. C., \& Tang, Q. (2012). Corporate Incentives to Disclose Carbon Information: Evidence from the CDP Global 500 Report. Journal of International Financial Management and Accounting, 23(2), 93-120. https://doi.org/10.1111/j.1467646X.2012.01055.x

Matsumura, E. M., Prakash, R., \& Vera-Muñoz, S. C. (2014). Firm-value effects of carbon emissions and carbon disclosures. The Accounting Review, 89(2), 695-724. https://doi.org/10.2308/accr-50629 
Meyer, J. W., \& Rowan, B. (1977). Institutionalized organizations: Formal structure as myth and ceremony. American Journal of Sociology, 83(2), 340-363.

https://doi.org/10.1086/226550

Minnis, M. (2011). The value of financial statement verification in debt financing: Evidence from private U.S. firms. Journal of Accounting Research, 49(2), 457-506. https://doi.org/10.1111/j.1475-679X.2011.00411.x

Niedertscheider, M., Haas, W., and Görg, C. (2018). Austrian climate policies and GHGemissions since 1990: What is the role of climate policy integration? Environmental Science and Policy, 81, 10-17. https://doi.org/10.1016/j.envsci.2017.12.007

Qiu, Y., Shaukat, A., and Tharyan, R. (2016). Environmental and social disclosures: Link with corporate financial performance. British Accounting Review, 48(1), 102-116. https://doi.org/10.1016/j.bar.2014.10.007

Rosenbaum, P. R., \& Rubin, D. B. (1983). The central role of the propensity score in observational studies for causal effects. Biometrika, 70(1), 41-55. https://doi.org/10.1093/biomet/70.1.41

Rothenberg, S. (2007). Environmental managers as institutional entrepreneurs: The influence of institutional and technical pressures on waste management. Journal of Business Research, 60(7), 749-757. https://doi.org/10.1016/j.jbusres.2007.02.017

Ruiqi, W., Wang, F., Xu, L., \& Yuan, C. (2017). R\&D expenditures, ultimate ownership and future performance: Evidence from China. Journal of Business Research, 71, 47-54. https://doi.org/10.1016/j.jbusres.2016.10.018

Sadler, T. R. (2016). Institutional pressures and organizational characteristics: The case of polluting emissions and the toxics release inventory. Journal of Interdisciplinary Economics, 28(1), 1-23. https://doi.org/10.1177/0260107915609826

Sapienza, P. (2004). The effects of government ownership on bank lending. Journal of Financial Economics, 72(2), 357-384. https://doi.org/10.1016/j.jfineco.2002.10.002

Scott, W. R. (2006). The Adolescence of Institutional Theory. Administrative Science Quarterly, 32(4), 493-511. https://doi.org/10.2307/2392880

Sun, Y. (2018). China's Target Responsibility System and Convergence of $\mathrm{CO}_{2}$ Emissions. The Singapore Economic Review, 63(02), 431-445. https://doi.org/10.1142/S0217590817400197

Tang, Q. (2018). Institutional Influence, Transition Management and the Demand for Carbon Auditing: The Chinese Experience. Australian Accounting Review, forthcoming. https://doi.org/10.1111/auar.12224

Tauringana, V., \& Chithambo, L. (2015). The effect of DEFRA guidance on greenhouse gas disclosure. British Accounting Review, 47(4), 425-444.

https://doi.org/10.1016/j.bar.2014.07.002

Tingey-Holyoak, J. (2014). Sustainable water storage by agricultural businesses: Strategic responses to institutional pressures. Journal of Business Research, 67(12), 2590-2602. 
https://doi.org/10.1016/j.jbusres.2014.03.018

Wang, F., Xu, L., Zhang, J., \& Shu, W. (2018). Political connections, internal control and firm value: Evidence from China's anti-corruption campaign. Journal of Business Research, 86, 53-67. https://doi.org/10.1016/j.jbusres.2018.01.045

Wei, S. J., \& Wang, T. (1997). The Siamese twins: do state-owned banks favor state-owned enterprises in China?. China Economic Review, 8(1), 19-29. https://doi.org/10.1016/S1043-951X(97)90010-9

Wiseman, J. (1982). An evaluation of environmental disclosures made in corporate annual reports. Accounting, Organizations and Society, 7(1), 53-63. https://doi.org/10.1016/0361-3682(82)90025-3

Wong T J. (2016). Corporate governance research on listed firms in China: Institutions, governance and accountability. Foundations and Trends ${ }^{\circledR}$ in Accounting, 9(4): 259-326. http://dx.doi.org/10.1561/1400000039

$\mathrm{Xu}, \mathrm{C}$. (2011). The fundamental institutions of China's reforms and development. Journal of Economic Literature, 49(4), 1076-1151. https://doi.org/10.2469/dig.v42.n3.11

Yen, D. A., \& Abosag, I. (2016). Localization in China: How guanxi moderates Sino-US business relationships. Journal of Business Research, 69(12), 5724-5734. https://doi.org/10.1016/j.jbusres.2016.05.002

Yuan, X., \& Zuo, J. (2011). Transition to low carbon energy policies in China-from the Five-Year Plan perspective. Energy Policy, 39(6), 3855-3859. https://doi.org/10.1016/j.enpol.2011.04.017

Zhao, M. (2012). CSR-Based political legitimacy strategy: Managing the state by doing good in China and Russia. Journal of Business Ethics, 111(4), 439-460. https://doi.org/10.1007/s10551-012-1209-6. 
Table 1 Regional carbon reduction evaluation grades and rankings of year 2013 and 2014 from NDRC website

\begin{tabular}{|c|c|c|c|c|}
\hline Provinces & $\begin{array}{l}\text { Evaluation grades } \\
\text { of year } 2013\end{array}$ & $\begin{array}{l}\text { Evaluation rankings } \\
\text { of year } 2013\end{array}$ & $\begin{array}{l}\text { Evaluation grades } \\
\text { of year } 2014\end{array}$ & $\begin{array}{c}\text { Evaluation rankings } \\
\text { of year } 2014\end{array}$ \\
\hline Anhui & Outstanding & 18 & Outstanding & 11 \\
\hline Beijing & Outstanding & 4 & Outstanding & 1 \\
\hline Chongqing & Outstanding & 5 & Outstanding & 15 \\
\hline Fujian & Outstanding & 19 & Good & 21 \\
\hline Gansu & Good & 24 & Good & 27 \\
\hline Guangdong & Outstanding & 3 & Outstanding & 13 \\
\hline Guangxi & Fail & 29 & Outstanding & 14 \\
\hline Guizhou & Good & 20 & Outstanding & 17 \\
\hline Hainan & Good & 26 & Good & 26 \\
\hline Hebei & Outstanding & 17 & Outstanding & 3 \\
\hline Henan & Good & 23 & Good & 24 \\
\hline Heilongjiang & Good & 25 & Good & 20 \\
\hline Hubei & Outstanding & 8 & Outstanding & 12 \\
\hline Hunan & Good & 22 & Good & 25 \\
\hline Jilin & Outstanding & 7 & Outstanding & 7 \\
\hline Jiangsu & Outstanding & 2 & Outstanding & 9 \\
\hline Jiangxi & Good & 21 & Good & 22 \\
\hline Liaoning & Outstanding & 15 & Outstanding & 6 \\
\hline Inner Mongoria & Outstanding & 14 & Outstanding & 5 \\
\hline Ningxia & Pass & 27 & Good & 29 \\
\hline Qinghai & Fail & 31 & Good & 28 \\
\hline Shandong & Outstanding & 16 & Good & 23 \\
\hline Shanxi & Outstanding & 6 & Outstanding & 4 \\
\hline Shaanxi & Outstanding & 13 & Outstanding & 19 \\
\hline Shanghai & Outstanding & 1 & Outstanding & 8 \\
\hline Sichuan & Outstanding & 10 & Outstanding & 16 \\
\hline Tianjing & Outstanding & 11 & Outstanding & 2 \\
\hline Tibet & Pass & 28 & Pass & 30 \\
\hline Xinjiang & Fail & 30 & Pass & 31 \\
\hline Yunnan & Outstanding & 9 & Outstanding & 18 \\
\hline Zhejiang & Outstanding & 12 & Outstanding & 10 \\
\hline
\end{tabular}


Table 2 Variable definitions

\begin{tabular}{|c|c|c|}
\hline Variables & Descriptions & Source \\
\hline \multicolumn{3}{|c|}{ Dependent Variables } \\
\hline CRE1 & $\begin{array}{l}\text { Corporate carbon reduction engagement, which is coded as } 2 \text { if quantitative information is disclosed in the annual/CSR reports, } \\
\text { coded as } 1 \text { if only qualitative information is disclosed in year } t \text {, and } 0 \text { otherwise. }\end{array}$ & Manually Coded \\
\hline CRE2 & Corporate carbon reduction engagement, which is measured as the energy saving scores in year $t$. & HeXun website \\
\hline$C R E 1 \_D$ & Dummy variable of $C R E 1$, which is coded as 1 if the value of $C R E 1$ is larger than 0 in year $\mathrm{t}$, and 0 otherwise. & Manually Coded \\
\hline CRE2_D & Dummy variable of $C R E 2$, which is coded as 1 if the value of $C R E 2$ is larger than 0 in year $\mathrm{t}$, and 0 otherwise. & HeXun website \\
\hline Loanstate & Dummy variable that equals 1 if a firm gets one or more loans from a state-owned bank, and 0 otherwise. & CSMAR database \\
\hline Subsidies & The total amount of the carbon related subsidies scaled by the total revenue in year $t$. & CSMAR database \\
\hline
\end{tabular}

\section{Independent Variables}

IP Institutional pressure that equals 1,2,3, and 4 when NDRC's evaluation grades is outstanding, good, pass, and fail, respectively,

in the last year (see Table 1).
$I P \_R$

Table 1).
.

Table 1 )
Moderator variable

Ultimate ownership of listed companies, which is a dummy variable that is coded as 1 if the ultimate owner belongs to the
government or government-controlled institutions in year $t$, and 0 otherwise.

Control Variables

GDPgrowth Percentage of GDP growth in the province where a firm operated in year $\mathrm{t}$.

Area Area distinction that is coded as 1 if the firm operated in eastern provinces such as Shanghai and Jiangsu, and 0 otherwise.

$I N D D \quad$ Industry difference that is coded as 1 if firm is in a high pollution industry in year $t$, and 0 otherwise.

Export Degree of internationalization, which is the ratio of firm's foreign sales to its total sales in year t.

Marketshare Competitive position, which is the ratio of a firm's sales to the total amount of industry sales in year t.

Invest The increase of fixed assets and construction scaled by total assets in year $\mathrm{t}$.

II Percentage of total outstanding shares that is held by institutional investors in year $t$.

F1 Percentage of total outstanding shares that is held by the largest shareholder in year $t$.

Director Total number of directors at the end of year $\mathrm{t}$.

BTM Book-to-market ratio, which is the ratio of the book value to market value of equity in year t.

Size Natural logarithm of the book value of total assets in year $\mathrm{t}$.

Lev $\quad$ Book value of total liabilities scaled by total assets in year $\mathrm{t}$.

ROA Net income scaled by total assets in year $\mathrm{t}$.

TOA Tangible assets scaled by total assets in year t.

CFO Ratio of the net cash flow divided by total assets in year $\mathrm{t}$.

Age Number of publicly listed years of a company in year t.

Htax High tax rate condition that equals 1 if the company's income tax rate is greater than the statutory $25 \%$ in year $\mathrm{t}$, and 0 otherwise.

Manually Coded

Manually Coded

CSMAR database

CSMAR database

CSMAR database

NDRC website

CSMAR database

CSMAR database

CSMAR database

CSMAR database

CSMAR database

CSMAR database

CSMAR database

CSMAR database

CSMAR database

CSMAR database

CSMAR database

CSMAR database

CSMAR database 

year $t$. 
Table 3 Descriptive statistics

\begin{tabular}{|c|c|c|c|c|c|c|c|c|}
\hline Variable & $\mathrm{N}$ & Mean & Min & Max & $\mathrm{Sd}$ & $\mathrm{P} 25$ & P50 & P75 \\
\hline CRE1 & 4663 & 0.264 & 0 & 2 & 0.618 & 0 & 0 & 0 \\
\hline CRE1_D & 4663 & 0.171 & 0 & 1 & 0.377 & 0 & 0 & 0 \\
\hline CRE2 & 4663 & 0.333 & 0 & 7 & 1.261 & 0 & 0 & 0 \\
\hline CRE2_D & 4663 & 0.077 & 0 & 1 & 0.267 & 0 & 0 & 0 \\
\hline$I P$ & 4663 & 1.222 & 1 & 4 & 0.525 & 1 & 1 & 1 \\
\hline$I P \_R$ & 4663 & 11.64 & 1 & 31 & 7.894 & 4 & 11 & 17 \\
\hline SOE & 4663 & 0.395 & 0 & 1 & 0.489 & 0 & 0 & 1 \\
\hline GDPgrowth & 4663 & 0.071 & 0.000 & 0.129 & 0.023 & 0.064 & 0.077 & 0.085 \\
\hline Area & 4663 & 0.694 & 0 & 1 & 0.461 & 0 & 1 & 1 \\
\hline$I N D D$ & 4663 & 0.551 & 0 & 1 & 0.498 & 0 & 1 & 1 \\
\hline Export & 4663 & 7.391 & 0 & 82.27 & 16.54 & 0 & 0 & 4.925 \\
\hline Marketshare & 4663 & 0.015 & 0 & 0.235 & 0.035 & 0.001 & 0.004 & 0.011 \\
\hline Invest & 4663 & 0.014 & -0.105 & 0.175 & 0.036 & -0.002 & 0.006 & 0.023 \\
\hline II & 4663 & 1.750 & 0 & 32.94 & 4.690 & 0 & 0 & 1.332 \\
\hline$F 1$ & 4663 & 34.83 & 8.540 & 75.25 & 15.03 & 22.95 & 32.90 & 44.98 \\
\hline Director & 4663 & 8.611 & 5 & 15 & 1.711 & 7 & 9 & 9 \\
\hline BTM & 4663 & 0.729 & 0.054 & 4.189 & 0.746 & 0.269 & 0.476 & 0.867 \\
\hline Size & 4663 & 22.14 & 19.48 & 25.97 & 1.271 & 21.26 & 21.98 & 22.85 \\
\hline Lev & 4663 & 0.441 & 0.052 & 0.938 & 0.214 & 0.267 & 0.429 & 0.607 \\
\hline$R O A$ & 4663 & 0.032 & -0.199 & 0.188 & 0.055 & 0.010 & 0.030 & 0.060 \\
\hline Loanstate & 4663 & 0.376 & 0 & 1 & 0.484 & 0 & 0 & 1 \\
\hline Subsidies & 4663 & 0.149 & 0 & 3.507 & 0.459 & 0 & 0.006 & 0.087 \\
\hline TOA & 4663 & 0.637 & 0.196 & 0.938 & 0.162 & 0.531 & 0.650 & 0.759 \\
\hline$C F O$ & 4663 & 0.006 & -0.131 & 0.192 & 0.047 & -0.015 & 0.002 & 0.022 \\
\hline Age & 4663 & 17.09 & 6 & 29 & 5.248 & 14 & 17 & 22 \\
\hline Htax & 4663 & 0.439 & 0 & 1 & 0.496 & 0 & 0 & 1 \\
\hline$E T$ & 4663 & 0.093 & 0 & 1 & 0.290 & 0 & 0 & 0 \\
\hline LSubsidies & 4663 & 0.165 & 0 & 4.178 & 0.546 & 0 & 0.002 & 0.081 \\
\hline
\end{tabular}


Table 4 The impact of institutional pressure on corporate carbon reduction engagement

\begin{tabular}{|c|c|c|c|c|c|c|c|c|}
\hline & \multicolumn{8}{|c|}{ Carbon Reduction Engagement } \\
\hline & \multicolumn{4}{|c|}{ Reporting (CRE1) } & \multicolumn{4}{|c|}{ Performance (CRE2) } \\
\hline & $\begin{array}{c}\text { Model(1) } \\
4-1\end{array}$ & $\begin{array}{c}\text { Model(1) } \\
4-2\end{array}$ & $\begin{array}{c}\text { Model(1) } \\
4-3\end{array}$ & $\begin{array}{c}\text { Model(1) } \\
4-4\end{array}$ & $\begin{array}{c}\text { Model(1) } \\
4-5\end{array}$ & $\begin{array}{c}\text { Model(1) } \\
4-6\end{array}$ & $\begin{array}{c}\text { Model(1) } \\
4-7\end{array}$ & $\begin{array}{c}\text { Model(1) } \\
4-8\end{array}$ \\
\hline \multirow[t]{2}{*}{$I P$} & $0.036^{* *}$ & $0.030^{* *}$ & $0.038 * * *$ & $0.031 * *$ & $0.212 * * *$ & $0.210 * * *$ & $0.206^{* * *}$ & $0.203 * * *$ \\
\hline & $(2.679)$ & $(2.145)$ & $(2.756)$ & $(2.220)$ & $(4.198)$ & $(3.995)$ & $(4.088)$ & $(3.869)$ \\
\hline \multirow[t]{2}{*}{$S O E$} & $0.126 * * *$ & $0.114 * * *$ & $0.126^{* * *}$ & $0.114 * * *$ & $0.107 *$ & $0.127^{* *}$ & $0.108^{*}$ & $0.126^{* *}$ \\
\hline & $(5.937)$ & $(5.503)$ & $(5.937)$ & $(5.527)$ & $(1.992)$ & $(2.269)$ & $(2.007)$ & $(2.242)$ \\
\hline \multirow[t]{2}{*}{ GDPgrowth } & 0.218 & 0.337 & -0.021 & 0.127 & -0.031 & 0.206 & 0.864 & 1.074 \\
\hline & $(0.402)$ & $(0.598)$ & $(-0.038)$ & $(0.223)$ & $(-0.032)$ & $(0.209)$ & $(0.863)$ & $(1.059)$ \\
\hline \multirow[t]{2}{*}{ Area } & $0.034 *$ & $0.046^{* *}$ & $0.035^{*}$ & $0.047 * *$ & 0.061 & 0.071 & 0.058 & 0.068 \\
\hline & $(1.683)$ & $(2.087)$ & $(1.724)$ & $(2.113)$ & $(1.321)$ & $(1.534)$ & (1.255) & (1.489) \\
\hline \multirow[t]{2}{*}{$I N D D$} & $0.088 * * *$ & 0.031 & $0.089 * * *$ & 0.033 & $0.091 *$ & -0.062 & $0.088^{*}$ & -0.070 \\
\hline & $(3.651)$ & $(0.878)$ & (3.692) & $(0.898)$ & (1.985) & $(-0.648)$ & (1.903) & $(-0.768)$ \\
\hline \multirow[t]{2}{*}{ Export } & 0.000 & 0.001 & 0.000 & 0.000 & 0.001 & 0.001 & 0.002 & 0.002 \\
\hline & (1.005) & (1.335) & (0.664) & $(0.991)$ & $(0.907)$ & $(0.826)$ & (1.253) & (1.186) \\
\hline \multirow[t]{2}{*}{ Marketshare } & $1.318^{* *}$ & $1.590 * *$ & $1.305^{* *}$ & $1.570 * *$ & 1.243 & -0.322 & 1.292 & -0.239 \\
\hline & (2.644) & $(2.570)$ & (2.627) & $(2.542)$ & (1.357) & $(-0.314)$ & (1.406) & $(-0.230)$ \\
\hline \multirow[t]{2}{*}{ Invest } & -0.107 & -0.325 & -0.122 & -0.336 & -0.405 & -0.574 & -0.350 & -0.527 \\
\hline & $(-0.428)$ & $(-1.285)$ & $(-0.487)$ & $(-1.329)$ & $(-0.769)$ & $(-1.137)$ & $(-0.658)$ & $(-1.037)$ \\
\hline \multirow[t]{2}{*}{$I I$} & 0.003 & 0.002 & 0.001 & 0.001 & $-0.012 * * *$ & $-0.012 * * *$ & $-0.007 * *$ & $-0.008 * *$ \\
\hline & $(0.888)$ & $(0.830)$ & $(0.509)$ & $(0.506)$ & $(-3.485)$ & $(-3.531)$ & $(-2.081)$ & $(-2.177)$ \\
\hline \multirow[t]{2}{*}{$F 1$} & 0.000 & 0.000 & 0.000 & 0.000 & $-0.004 * * *$ & $-0.004 * * *$ & $-0.004 * * *$ & $-0.004 * * *$ \\
\hline & $(0.645)$ & $(0.911)$ & $(0.537)$ & $(0.822)$ & $(-3.089)$ & $(-2.867)$ & $(-2.942)$ & $(-2.742)$ \\
\hline \multirow[t]{2}{*}{ Director } & $0.021 * * *$ & $0.020 * * *$ & $0.020 * * *$ & $0.020 * * *$ & -0.017 & -0.012 & -0.015 & -0.010 \\
\hline & (3.316) & (3.269) & (3.294) & $(3.261)$ & $(-1.179)$ & $(-0.860)$ & $(-1.033)$ & $(-0.734)$ \\
\hline \multirow[t]{2}{*}{ BTM } & -0.016 & -0.014 & -0.024 & -0.022 & $-0.130 * *$ & $-0.133 * * *$ & $-0.098^{*}$ & $-0.101 *$ \\
\hline & $(-0.600)$ & $(-0.513)$ & $(-0.833)$ & $(-0.719)$ & $(-2.647)$ & $(-2.999)$ & $(-1.783)$ & $(-1.986)$ \\
\hline \multirow[t]{2}{*}{ Size } & $0.179 * * *$ & $0.173^{* * *}$ & $0.184 * * *$ & $0.177 * * *$ & $0.222 * * *$ & $0.248 * * *$ & $0.205^{* * *}$ & $0.230 * * *$ \\
\hline & (13.501) & (12.599) & $(13.472)$ & (12.318) & $(5.852)$ & $(6.142)$ & (5.018) & (5.264) \\
\hline \multirow[t]{2}{*}{ Lev } & $-0.198 * *$ & $-0.143^{*}$ & $-0.196 * *$ & $-0.142^{*}$ & -0.117 & -0.091 & -0.125 & -0.097 \\
\hline & $(-2.609)$ & $(-1.817)$ & $(-2.554)$ & $(-1.783)$ & $(-1.101)$ & $(-0.878)$ & $(-1.182)$ & $(-0.938)$ \\
\hline \multirow[t]{2}{*}{$R O A$} & -0.288 & -0.291 & -0.307 & -0.310 & $1.096^{* *}$ & $1.144 * *$ & $1.170 * * *$ & $1.224 * * *$ \\
\hline & $(-1.182)$ & $(-1.333)$ & $(-1.287)$ & $(-1.453)$ & $(2.565)$ & $(2.560)$ & $(2.740)$ & $(2.736)$ \\
\hline \multirow[t]{2}{*}{ Constant } & $-3.996 * * *$ & $-3.904 * * *$ & $-4.050 * * *$ & $-3.962 * * *$ & $-4.569 * * *$ & $-5.291 * * *$ & $-4.366^{* * *}$ & $-5.053 * * *$ \\
\hline & $(-14.071)$ & $(-13.349)$ & $(-13.883)$ & $(-12.980)$ & $(-5.808)$ & $(-6.222)$ & $(-5.350)$ & $(-5.675)$ \\
\hline Industry & No & Yes & No & Yes & No & Yes & No & Yes \\
\hline Year & No & No & Yes & Yes & No & No & Yes & Yes \\
\hline Observations & 4663 & 4663 & 4663 & 4663 & 4663 & 4663 & 4663 & 4663 \\
\hline Adj. $R^{2}$ & 0.194 & 0.203 & 0.194 & 0.203 & 0.044 & 0.052 & 0.046 & 0.054 \\
\hline
\end{tabular}

Note: Two-tailed robust t-statistics in parentheses are clustered at the industry level; *, **, and *** denote statistically significant at $0.10,0.05$, and 0.01 levels, respectively. 
Table 5 The moderating role of ultimate ownership on the relationship between institutional pressure and corporate carbon reduction engagement

\begin{tabular}{|c|c|c|c|c|c|c|}
\hline & \multicolumn{6}{|c|}{ Carbon Reduction Engagement } \\
\hline & \multicolumn{3}{|c|}{ Reporting (CREI) } & \multicolumn{3}{|c|}{ Performance (CRE2) } \\
\hline & $\begin{array}{c}\text { SOEs } \\
\text { Model(1) } \\
5-1\end{array}$ & $\begin{array}{c}\text { NSOEs } \\
\text { Model(1) } \\
5-2\end{array}$ & $\begin{array}{c}\text { Full sample } \\
\text { Model(2) } \\
5-3\end{array}$ & $\begin{array}{c}\text { SOEs } \\
\text { Model(1) } \\
5-4\end{array}$ & $\begin{array}{c}\text { NSOEs } \\
\text { Model(1) } \\
5-5\end{array}$ & $\begin{array}{c}\text { Full sample } \\
\text { Model(2) } \\
5-6\end{array}$ \\
\hline$I P$ & 0.003 & $0.076^{* * *}$ & $0.043^{* * *}$ & $0.164 * *$ & $0.278 * * *$ & $0.222 * * *$ \\
\hline & $(0.126)$ & (3.162) & (2.669) & $(2.513)$ & $(4.055)$ & $(4.238)$ \\
\hline SOE & & & $\begin{array}{c}0.116^{* * *} \\
(5.575)\end{array}$ & & & $\begin{array}{c}0.129 * * \\
(2.328)\end{array}$ \\
\hline$I P * S O E$ & & & $\begin{array}{c}-0.082 * * \\
(-2.554)\end{array}$ & & & $\begin{array}{l}-0.139^{*} \\
(-1.765)\end{array}$ \\
\hline GDPgrowth & $\begin{array}{c}0.679 \\
(0.712)\end{array}$ & $\begin{array}{c}-0.497 \\
(-0.764)\end{array}$ & $\begin{array}{c}0.139 \\
(0.242)\end{array}$ & $\begin{array}{c}2.477 \\
(1.244)\end{array}$ & $\begin{array}{c}0.122 \\
(0.111)\end{array}$ & $\begin{array}{c}1.095 \\
(1.075)\end{array}$ \\
\hline Area & $\begin{array}{c}0.038 \\
(0.924)\end{array}$ & $\begin{array}{l}0.053 * \\
(1.906)\end{array}$ & $\begin{array}{c}0.049 * * \\
(2.178)\end{array}$ & $\begin{array}{c}0.066 \\
(0.848)\end{array}$ & $\begin{array}{c}0.087 \\
(1.606)\end{array}$ & $\begin{array}{c}0.071 \\
(1.582)\end{array}$ \\
\hline$I N D D$ & $\begin{array}{c}0.017 \\
(0.234)\end{array}$ & $\begin{array}{c}0.150 * * \\
(2.389)\end{array}$ & $\begin{array}{c}0.035 \\
(0.874)\end{array}$ & $\begin{array}{c}-0.014 \\
(-0.141)\end{array}$ & $\begin{array}{c}-0.006 \\
(-0.034)\end{array}$ & $\begin{array}{c}-0.068 \\
(-0.690)\end{array}$ \\
\hline Export & $\begin{array}{c}0.003 * * \\
(2.116)\end{array}$ & $\begin{array}{c}-0.000 \\
(-0.788)\end{array}$ & $\begin{array}{c}0.000 \\
(1.003)\end{array}$ & $\begin{array}{c}0.004 \\
(1.353)\end{array}$ & $\begin{array}{c}0.001 \\
(0.608)\end{array}$ & $\begin{array}{c}0.002 \\
(1.195)\end{array}$ \\
\hline Marketshare & $\begin{array}{c}0.838 \\
(1.227)\end{array}$ & $\begin{array}{c}1.744 \\
(1.642)\end{array}$ & $\begin{array}{l}1.531 * * \\
(2.498)\end{array}$ & $\begin{array}{c}-1.129 \\
(-1.205)\end{array}$ & $\begin{array}{c}0.378 \\
(0.199)\end{array}$ & $\begin{array}{c}-0.305 \\
(-0.299)\end{array}$ \\
\hline Invest & $\begin{array}{c}-0.074 \\
(-0.160)\end{array}$ & $\begin{array}{c}-0.315 \\
(-1.277)\end{array}$ & $\begin{array}{c}-0.331 \\
(-1.310)\end{array}$ & $\begin{array}{c}-0.385 \\
(-0.425)\end{array}$ & $\begin{array}{c}-0.450 \\
(-0.734)\end{array}$ & $\begin{array}{c}-0.519 \\
(-1.017)\end{array}$ \\
\hline II & $\begin{array}{c}0.000 \\
(0.006)\end{array}$ & $\begin{array}{c}0.003 \\
(0.792)\end{array}$ & $\begin{array}{c}0.001 \\
(0.504)\end{array}$ & $\begin{array}{l}-0.010^{*} \\
(-1.686)\end{array}$ & $\begin{array}{c}-0.006 \\
(-1.323)\end{array}$ & $\begin{array}{l}-0.008^{* *} \\
(-2.190)\end{array}$ \\
\hline$F 1$ & $\begin{array}{l}0.002 * \\
(1.845)\end{array}$ & $\begin{array}{c}-0.001 \\
(-1.208)\end{array}$ & $\begin{array}{c}0.000 \\
(0.881)\end{array}$ & $\begin{array}{c}-0.004 \\
(-1.357)\end{array}$ & $\begin{array}{c}-0.003 \\
(-1.428)\end{array}$ & $\begin{array}{c}-0.004 * * * \\
(-2.703)\end{array}$ \\
\hline Director & $\begin{array}{c}0.017 \\
(1.675)\end{array}$ & $\begin{array}{c}0.021 * * \\
(2.682)\end{array}$ & $\begin{array}{c}0.020 * * * \\
(3.229)\end{array}$ & $\begin{array}{c}-0.004 \\
(-0.171)\end{array}$ & $\begin{array}{c}-0.012 \\
(-0.623)\end{array}$ & $\begin{array}{c}-0.011 \\
(-0.745)\end{array}$ \\
\hline BTM & $\begin{array}{c}-0.019 \\
(-0.417)\end{array}$ & $\begin{array}{l}-0.067^{*} \\
(-1.821)\end{array}$ & $\begin{array}{c}-0.020 \\
(-0.635)\end{array}$ & $\begin{array}{c}-0.060 \\
(-0.986)\end{array}$ & $\begin{array}{c}-0.080 \\
(-0.681)\end{array}$ & $\begin{array}{l}-0.097^{*} \\
(-1.907)\end{array}$ \\
\hline Size & $\begin{array}{c}0.230 * * * \\
(9.108)\end{array}$ & $\begin{array}{c}0.135 * * * \\
(7.666)\end{array}$ & $\begin{array}{c}0.176 * * * \\
(12.299)\end{array}$ & $\begin{array}{c}0.230 * * * \\
(3.125)\end{array}$ & $\begin{array}{c}0.207 * * * \\
(3.645)\end{array}$ & $\begin{array}{c}0.228 * * * \\
(5.188)\end{array}$ \\
\hline Lev & $\begin{array}{c}-0.293 * * \\
(-2.239)\end{array}$ & $\begin{array}{c}-0.024 \\
(-0.350)\end{array}$ & $\begin{array}{l}-0.138^{*} \\
(-1.765)\end{array}$ & $\begin{array}{c}-0.458 * * \\
(-2.142)\end{array}$ & $\begin{array}{c}0.078 \\
(0.600)\end{array}$ & $\begin{array}{c}-0.090 \\
(-0.853)\end{array}$ \\
\hline$R O A$ & $\begin{array}{l}-0.738^{*} \\
(-1.930)\end{array}$ & $\begin{array}{c}0.014 \\
(0.071)\end{array}$ & $\begin{array}{c}-0.309 \\
(-1.483)\end{array}$ & $\begin{array}{c}1.339 \\
(1.590)\end{array}$ & $\begin{array}{l}1.256^{* *} \\
(2.404)\end{array}$ & $\begin{array}{c}1.227 * * * \\
(2.772)\end{array}$ \\
\hline Constant & $\begin{array}{c}-5.094 * * * \\
(-9.212)\end{array}$ & $\begin{array}{c}-2.977 * * * \\
(-8.165)\end{array}$ & $\begin{array}{l}-3.945 * * * \\
(-12.995)\end{array}$ & $\begin{array}{c}-5.086^{* * * *} \\
(-3.421)\end{array}$ & $\begin{array}{c}-4.571 * * * \\
(-3.847)\end{array}$ & $\begin{array}{c}-5.026^{* * *} \\
(-5.679)\end{array}$ \\
\hline Industry/Year & Yes & Yes & Yes & Yes & Yes & Yes \\
\hline Diff. on $I P$ & \multicolumn{2}{|c|}{$5.54 * *$} & - & \multicolumn{2}{|c|}{1.84} & - \\
\hline Observations & 4663 & 4663 & 4663 & 4663 & 4663 & 4663 \\
\hline Adj. $R^{2}$ & 0.179 & 0.131 & 0.204 & 0.055 & 0.056 & 0.054 \\
\hline
\end{tabular}

Note: Two-tailed robust t-statistics in parentheses are clustered at the industry level; *, **, and ${ }^{* * *}$ denote statistically significant at $0.10,0.05$, and 0.01 levels, respectively. 
Table 6 Effect of corporate carbon reduction engagement on firms' access to state-owned bank loans and government subsidies varying in SOEs and NSOEs

\begin{tabular}{|c|c|c|c|c|c|c|c|c|}
\hline & $\begin{array}{c}\text { Loanstate } \\
\text { SOEs } \\
\text { Model(3) } \\
6-1\end{array}$ & $\begin{array}{c}\text { Loanstate } \\
\text { NSOEs } \\
\text { Model(3) } \\
6-2\end{array}$ & $\begin{array}{c}\text { Subsidy } \\
\text { SOEs } \\
\text { Model(4) } \\
6-3\end{array}$ & $\begin{array}{c}\text { Subsidy } \\
\text { NSOEs } \\
\text { Model(4) } \\
6-4\end{array}$ & $\begin{array}{l}\text { Loanstate } \\
\text { SOEs } \\
\text { Model(3) } \\
6-5\end{array}$ & $\begin{array}{c}\text { Loanstate } \\
\text { NSOEs } \\
\text { Model(3) } \\
6-6\end{array}$ & $\begin{array}{c}\text { Subsidy } \\
\text { SOEs } \\
\text { Model(4) } \\
6-7\end{array}$ & $\begin{array}{c}\text { Subsidy } \\
\text { NSOEs } \\
\text { Model(4) } \\
6-8\end{array}$ \\
\hline CRE1 & $\begin{array}{l}0.018 \\
(0.40)\end{array}$ & $\begin{array}{c}0.180 * * * \\
(3.09)\end{array}$ & $\begin{array}{l}0.008 \\
(0.65)\end{array}$ & $\begin{array}{l}0.006 \\
(0.39)\end{array}$ & & & & \\
\hline CRE2 & & & & & $\begin{array}{l}-0.036 \\
(-1.56)\end{array}$ & $\begin{array}{c}0.044 * \\
(1.93)\end{array}$ & $\begin{array}{l}0.002 \\
(0.30)\end{array}$ & $\begin{array}{l}0.010 \\
(1.61)\end{array}$ \\
\hline Area & $\begin{array}{l}0.053 \\
(0.78)\end{array}$ & $\begin{array}{c}0.122 * * \\
(2.01)\end{array}$ & $\begin{array}{l}0.002 \\
(0.11)\end{array}$ & $\begin{array}{l}-0.023 \\
(-1.32)\end{array}$ & $\begin{array}{l}0.056 \\
(0.82)\end{array}$ & $\begin{array}{c}0.127 * * \\
(2.10)\end{array}$ & $\begin{array}{l}0.002 \\
(0.13)\end{array}$ & $\begin{array}{l}-0.022 \\
(-1.31)\end{array}$ \\
\hline$I N D D$ & $\begin{array}{l}-0.217 \\
(-1.42)\end{array}$ & $\begin{array}{l}-0.216 \\
(-0.58)\end{array}$ & $\begin{array}{l}0.014 \\
(0.31)\end{array}$ & $\begin{array}{c}-0.293^{* * *} \\
(-3.00)\end{array}$ & $\begin{array}{l}-0.218 \\
(-1.42)\end{array}$ & $\begin{array}{l}-0.191 \\
(-0.51)\end{array}$ & $\begin{array}{l}0.014 \\
(0.32)\end{array}$ & $\begin{array}{c}-0.292 * * * \\
(-2.99)\end{array}$ \\
\hline BTM & $\begin{array}{l}0.072 \\
(1.21)\end{array}$ & $\begin{array}{c}0.142 * \\
(1.76)\end{array}$ & $\begin{array}{l}0.013 \\
(0.80)\end{array}$ & $\begin{array}{l}0.010 \\
(0.42)\end{array}$ & $\begin{array}{l}0.070 \\
(1.18)\end{array}$ & $\begin{array}{l}0.133 \\
(1.64)\end{array}$ & $\begin{array}{l}0.013 \\
(0.79)\end{array}$ & $\begin{array}{l}0.010 \\
(0.44)\end{array}$ \\
\hline Size & $\begin{array}{c}-0.067 * \\
(-1.71)\end{array}$ & $\begin{array}{c}0.061 * \\
(1.66)\end{array}$ & $\begin{array}{c}-0.019 * \\
(-1.72)\end{array}$ & $\begin{array}{l}-0.009 \\
(-0.91)\end{array}$ & $\begin{array}{l}-0.056 \\
(-1.48)\end{array}$ & $\begin{array}{c}0.081 * * \\
(2.27)\end{array}$ & $\begin{array}{l}-0.017 \\
(-1.62)\end{array}$ & $\begin{array}{l}-0.010 \\
(-1.04)\end{array}$ \\
\hline Lev & $\begin{array}{c}0.860 * * * \\
(3.94)\end{array}$ & $\begin{array}{c}0.735^{* * * *} \\
(4.48)\end{array}$ & $\begin{array}{l}0.067 \\
(1.10)\end{array}$ & $\begin{array}{l}0.025 \\
(0.53)\end{array}$ & $\begin{array}{c}0.841 * * * \\
(3.85)\end{array}$ & $\begin{array}{c}0.727 * * * \\
(4.44)\end{array}$ & $\begin{array}{l}0.066 \\
(1.08)\end{array}$ & $\begin{array}{l}0.024 \\
(0.52)\end{array}$ \\
\hline$R O A$ & $\begin{array}{c}-1.280 * \\
(-1.80)\end{array}$ & $\begin{array}{l}-0.078 \\
(-0.15)\end{array}$ & $\begin{array}{l}0.238 \\
(1.18)\end{array}$ & $\begin{array}{l}-0.147 \\
(-0.98)\end{array}$ & $\begin{array}{c}-1.259 * \\
(-1.77)\end{array}$ & $\begin{array}{l}-0.127 \\
(-0.24)\end{array}$ & $\begin{array}{l}0.229 \\
(1.14)\end{array}$ & $\begin{array}{l}-0.160 \\
(-1.07)\end{array}$ \\
\hline$F 1$ & $\begin{array}{l}0.001 \\
(0.25)\end{array}$ & $\begin{array}{l}-0.000 \\
(-0.00)\end{array}$ & $\begin{array}{l}0.000 \\
(0.20)\end{array}$ & $\begin{array}{l}-0.000 \\
(-0.46)\end{array}$ & $\begin{array}{l}0.001 \\
(0.25)\end{array}$ & $\begin{array}{l}-0.000 \\
(-0.03)\end{array}$ & $\begin{array}{l}0.000 \\
(0.24)\end{array}$ & $\begin{array}{l}-0.000 \\
(-0.41)\end{array}$ \\
\hline TOA & $\begin{array}{c}-0.806 * * * \\
(-3.54)\end{array}$ & $\begin{array}{c}-0.336^{*} \\
(-1.91)\end{array}$ & & & $\begin{array}{c}-0.812 * * * \\
(-3.56)\end{array}$ & $\begin{array}{c}-0.310 * \\
(-1.76)\end{array}$ & & \\
\hline $\mathrm{CFO}$ & $\begin{array}{c}2.007 * * \\
(2.38)\end{array}$ & $\begin{array}{l}-0.216 \\
(-0.44)\end{array}$ & & & $\begin{array}{c}2.030 * * \\
(2.41)\end{array}$ & $\begin{array}{l}-0.245 \\
(-0.50)\end{array}$ & & \\
\hline Age & $\begin{array}{l}-0.004 \\
(-0.58)\end{array}$ & $\begin{array}{c}-0.015^{* * *} \\
(-3.10)\end{array}$ & & & $\begin{array}{l}-0.004 \\
(-0.58)\end{array}$ & $\begin{array}{c}-0.015 * * * \\
(-2.95)\end{array}$ & & \\
\hline Htax & & & $\begin{array}{l}0.011 \\
(0.50)\end{array}$ & $\begin{array}{l}-0.011 \\
(-0.61)\end{array}$ & & & $\begin{array}{l}0.011 \\
(0.51)\end{array}$ & $\begin{array}{l}-0.012 \\
(-0.64)\end{array}$ \\
\hline$E T$ & & & $\begin{array}{l}0.000 \\
(0.00)\end{array}$ & $\begin{array}{l}-0.004 \\
(-0.15)\end{array}$ & & & $\begin{array}{l}-0.000 \\
(-0.01)\end{array}$ & $\begin{array}{l}-0.004 \\
(-0.16)\end{array}$ \\
\hline LSubsidy & & & $\begin{array}{c}0.547 * * * \\
(35.97)\end{array}$ & $\begin{array}{c}0.401 * * * \\
(28.55)\end{array}$ & & & $\begin{array}{c}0.546^{* * * *} \\
(35.96)\end{array}$ & $\begin{array}{c}0.401 * * * \\
(28.50)\end{array}$ \\
\hline Constant & $\begin{array}{l}1.519 * \\
(1.77)\end{array}$ & $\begin{array}{c}-1.727 * * \\
(-2.14)\end{array}$ & $\begin{array}{c}(2.35) \\
0.549^{* *}\end{array}$ & $\begin{array}{l}(1.38) \\
0.300\end{array}$ & $\begin{array}{l}1.292 \\
(1.56)\end{array}$ & $\begin{array}{c}-2.166^{* * *} \\
(-2.75)\end{array}$ & $\begin{array}{c}0.512 * * \\
(2.27)\end{array}$ & $\begin{array}{l}0.323 \\
(1.51)\end{array}$ \\
\hline Industry/ Year & Yes & Yes & Yes & Yes & Yes & Yes & Yes & Yes \\
\hline Diff. on $C R E$ & \multicolumn{2}{|c|}{$5.01 * *$} & \multicolumn{2}{|c|}{0.01} & \multicolumn{2}{|c|}{$6.40 * *$} & \multicolumn{2}{|c|}{0.74} \\
\hline Observations & 1832 & 2803 & 1840 & 2823 & 1832 & 2803 & 1840 & 2823 \\
\hline Pseudo/Adj.R ${ }^{2}$ & 0.048 & 0.047 & 0.454 & 0.259 & 0.049 & 0.046 & 0.454 & 0.260 \\
\hline
\end{tabular}

Note: Two-tailed robust z/t-statistics in parentheses are clustered at the industry level; *,**, and *** denote statistically significant at $0.10,0.05$, and 0.01 levels, respectively. 
Table 7 Corporate carbon reduction engagement before and after the evaluation launched

\begin{tabular}{|c|c|c|c|c|}
\hline & CRE1 & CRE1 & CRE2 & CRE2 \\
\hline \multirow[t]{2}{*}{ Post } & $0.205^{* * *}$ & $0.167 * * *$ & $0.369 * * *$ & $0.139 *$ \\
\hline & (7.267) & (4.469) & (8.398) & (1.743) \\
\hline \multirow[t]{2}{*}{ Post*IP } & & $0.063^{* *}$ & & $0.379 * * *$ \\
\hline & & (2.038) & & (3.653) \\
\hline \multirow[t]{2}{*}{$S O E$} & $0.061 * * *$ & $0.060 * * *$ & $0.061 * *$ & $0.059 * *$ \\
\hline & $(5.381)$ & (5.327) & (2.166) & (2.053) \\
\hline \multirow[t]{2}{*}{ GDPgrowth } & -0.116 & -0.101 & 0.574 & 0.664 \\
\hline & $(-0.392)$ & $(-0.343)$ & $(1.262)$ & $(1.461)$ \\
\hline \multirow[t]{2}{*}{ Area } & 0.013 & $0.020 *$ & 0.001 & $0.040^{*}$ \\
\hline & (1.044) & (1.726) & $(0.060)$ & (1.884) \\
\hline \multirow[t]{2}{*}{$I N D D$} & 0.025 & 0.026 & -0.043 & -0.041 \\
\hline & (1.024) & (1.059) & $(-0.786)$ & $(-0.791)$ \\
\hline \multirow[t]{2}{*}{ Export } & 0.000 & $0.000 *$ & 0.001 & 0.001 \\
\hline & $(1.680)$ & $(1.682)$ & (1.393) & (1.424) \\
\hline \multirow[t]{2}{*}{ Marketshare } & $0.709 * *$ & $0.711 * *$ & -0.119 & -0.105 \\
\hline & $(2.591)$ & (2.598) & $(-0.250)$ & $(-0.222)$ \\
\hline \multirow[t]{2}{*}{ Invest } & -0.125 & -0.119 & -0.294 & -0.259 \\
\hline & $(-0.980)$ & $(-0.936)$ & $(-1.190)$ & $(-1.051)$ \\
\hline \multirow[t]{2}{*}{ II } & -0.001 & -0.001 & $-0.002 * *$ & $-0.003 * *$ \\
\hline & $(-0.598)$ & $(-0.633)$ & $(-2.031)$ & $(-2.201)$ \\
\hline \multirow[t]{2}{*}{$F 1$} & 0.000 & 0.000 & $-0.002 * * *$ & $-0.002 * * *$ \\
\hline & $(0.542)$ & $(0.544)$ & $(-2.868)$ & $(-2.863)$ \\
\hline \multirow[t]{2}{*}{ Director } & $0.009 * *$ & $0.009 * *$ & -0.007 & -0.006 \\
\hline & $(2.502)$ & $(2.516)$ & $(-0.900)$ & $(-0.828)$ \\
\hline \multirow[t]{2}{*}{$B T M$} & $-0.035 * * *$ & $-0.035 * * *$ & $-0.052 * * *$ & $-0.055 * * *$ \\
\hline & $(-2.777)$ & $(-2.802)$ & $(-2.741)$ & $(-2.836)$ \\
\hline \multirow[t]{2}{*}{ Size } & $0.099 * * *$ & $0.099 * * *$ & $0.121 * * *$ & $0.123 * * *$ \\
\hline & (13.506) & $(13.615)$ & (5.119) & $(5.351)$ \\
\hline \multirow[t]{2}{*}{ Lev } & -0.055 & -0.055 & -0.042 & -0.041 \\
\hline & $(-1.443)$ & $(-1.440)$ & $(-0.822)$ & $(-0.791)$ \\
\hline \multirow[t]{2}{*}{$R O A$} & $-0.230 * *$ & $-0.227 * *$ & $0.536^{* *}$ & $0.555^{* *}$ \\
\hline & $(-2.114)$ & $(-2.104)$ & (2.388) & $(2.533)$ \\
\hline \multirow[t]{2}{*}{ Constant } & $-2.242 * * *$ & $-2.262 * * *$ & $-2.555 * * *$ & $-2.678 * * *$ \\
\hline & $(-13.600)$ & $(-13.751)$ & $(-5.670)$ & $(-5.974)$ \\
\hline Industry/Year & Yes & Yes & Yes & Yes \\
\hline Observations & 9246 & 9246 & 9246 & 9246 \\
\hline Adj. $R^{2}$ & 0.176 & 0.176 & 0.060 & 0.065 \\
\hline
\end{tabular}

Note: Two-tailed robust $\mathrm{t}$-statistics in parentheses are clustered at the industry level; *, **, and *** denote statistically significant at $0.10,0.05$, and 0.01 levels, respectively. 
Table 8 Impact of institutional pressure on subsequent corporate carbon reduction engagement

\begin{tabular}{|c|c|c|c|c|}
\hline & CRE1 & CRE1 & CRE2 & CRE2 \\
\hline \multirow[t]{2}{*}{$I P_{t-1}$} & $0.068 * *$ & $0.090 * * *$ & $0.396 * * *$ & $0.465 * * *$ \\
\hline & (2.425) & $(2.771)$ & (5.727) & (4.927) \\
\hline \multirow[t]{2}{*}{$I P_{t-2}$} & $-0.051 * * *$ & -0.040 & -0.089 & $-0.137 * *$ \\
\hline & $(-2.966)$ & $(-1.665)$ & $(-1.240)$ & $(-2.208)$ \\
\hline \multirow[t]{2}{*}{$I P_{t-1} * S O E$} & & -0.059 & & -0.173 \\
\hline & & $(-0.746)$ & & $(-0.832)$ \\
\hline \multirow[t]{2}{*}{$I P_{t-2} * S O E$} & & -0.016 & & 0.103 \\
\hline & & $(-0.303)$ & & $(0.802)$ \\
\hline \multirow[t]{2}{*}{$S O E$} & $0.227 * * *$ & $0.321 * * *$ & $0.297 * * *$ & $0.385 * *$ \\
\hline & $(6.648)$ & (4.264) & (3.515) & (2.118) \\
\hline \multirow[t]{2}{*}{ GDPgrowth } & 0.387 & 0.391 & 0.083 & 0.083 \\
\hline & (1.305) & (1.310) & $(0.121)$ & $(0.121)$ \\
\hline \multirow[t]{2}{*}{ Area } & 0.042 & 0.043 & 0.072 & 0.070 \\
\hline & $(1.275)$ & (1.316) & $(0.882)$ & $(0.852)$ \\
\hline \multirow[t]{2}{*}{$I N D D$} & -0.178 & -0.173 & $-0.195 * *$ & $-0.186 * *$ \\
\hline & $(-1.454)$ & $(-1.383)$ & $(-2.221)$ & $(-2.163)$ \\
\hline \multirow[t]{2}{*}{ Export } & $0.002 *$ & $0.002 *$ & 0.002 & 0.002 \\
\hline & (1.903) & (1.906) & (0.988) & (0.987) \\
\hline \multirow[t]{2}{*}{ Marketshare } & 0.909 & 0.910 & 1.004 & 1.035 \\
\hline & (1.376) & (1.367) & $(0.553)$ & $(0.568)$ \\
\hline \multirow[t]{2}{*}{ Invest } & $-0.309 * * *$ & $-0.312 * * *$ & $-1.669 * * *$ & $-1.649 * * *$ \\
\hline & $(-3.800)$ & $(-3.885)$ & $(-4.544)$ & $(-4.426)$ \\
\hline \multirow[t]{2}{*}{ II } & $-0.003 *$ & $-0.003 *$ & 0.001 & 0.001 \\
\hline & $(-1.882)$ & $(-1.859)$ & (0.089) & $(0.088)$ \\
\hline \multirow[t]{2}{*}{$F 1$} & -0.001 & -0.001 & $-0.007 * * *$ & $-0.007 * * *$ \\
\hline & $(-1.591)$ & $(-1.674)$ & $(-3.730)$ & $(-3.783)$ \\
\hline \multirow[t]{2}{*}{ Director } & $0.025 * * *$ & $0.024 * * *$ & 0.005 & 0.004 \\
\hline & $(2.727)$ & $(2.731)$ & $(0.196)$ & $(0.175)$ \\
\hline \multirow[t]{2}{*}{$B T M$} & $-0.049 * * *$ & $-0.049 * * *$ & $-0.120 * * *$ & $-0.119 * * *$ \\
\hline & $(-3.169)$ & $(-3.159)$ & $(-5.467)$ & $(-5.417)$ \\
\hline \multirow[t]{2}{*}{ Size } & $0.197 * * *$ & $0.196 * * *$ & $0.402 * * *$ & $0.401 * * *$ \\
\hline & (10.368) & $(10.271)$ & $(10.045)$ & (9.884) \\
\hline \multirow[t]{2}{*}{ Lev } & -0.088 & -0.086 & $-0.316^{*}$ & $-0.323 * *$ \\
\hline & $(-1.324)$ & $(-1.273)$ & $(-2.011)$ & $(-2.057)$ \\
\hline \multirow[t]{2}{*}{$R O A$} & -0.190 & -0.196 & $0.704 *$ & 0.679 \\
\hline & $(-1.534)$ & $(-1.538)$ & $(1.751)$ & (1.671) \\
\hline \multirow[t]{2}{*}{ Constant } & $-4.389 * * *$ & $-4.402 * * *$ & $-8.419 * * *$ & $-8.414 * * *$ \\
\hline & $(-10.555)$ & $(-10.522)$ & $(-8.994)$ & $(-9.004)$ \\
\hline Industry & Yes & Yes & Yes & Yes \\
\hline Observations & 2636 & 2636 & 2636 & 2636 \\
\hline Adj. $R^{2}$ & 0.229 & 0.229 & 0.104 & 0.104 \\
\hline
\end{tabular}

Note: Two-tailed robust t-statistics in parentheses are clustered at the industry level; *, **, and *** denote statistically significant at $0.10,0.05$, and 0.01 levels, respectively. 
Table 9 Effect of institutional pressure on corporate carbon reduction engagement and moderating effect of ultimate ownership: robustness checks

\begin{tabular}{|c|c|c|c|c|}
\hline \multicolumn{5}{|c|}{ Panel A: Alternative regression model-negative binomial model } \\
\hline \multirow{4}{*}{$I P$} & CRE1 & CRE1 & CRE2 & CRE2 \\
\hline & Model(1) & Model(2) & Model(1) & Model(2) \\
\hline & $0.147 * * *$ & $0.217 * * *$ & $0.655^{* * *}$ & $0.709^{* * *}$ \\
\hline & (3.458) & (4.278) & $(3.254)$ & (3.589) \\
\hline \multirow{2}{*}{$I P * S O E$} & & $-0.272 * * *$ & & $-0.435^{*}$ \\
\hline & & $(-2.818)$ & & $(-1.681)$ \\
\hline
\end{tabular}

Panel B: Alternative measure of key variables

(1)Natural logarithm of $I P$

\begin{tabular}{lcccc} 
& CRE1 & $C R E 1$ & $C R E 2$ & $C R E 2$ \\
$\operatorname{Model}(1)$ & $\operatorname{Model}(2)$ & $\operatorname{Model}(1)$ & $\operatorname{Model}(2)$ \\
\cline { 2 - 5 } $\ln (I P)$ & $0.054^{* *}$ & $0.068^{* *}$ & $0.384^{* * *}$ & $0.408^{* * *}$ \\
& $(2.211)$ & $(2.557)$ & $(4.349)$ & $(4.659)$ \\
$\ln (I P) *$ SOE & & $-0.078^{* *}$ & & -0.126 \\
& & $(-2.440)$ & & $(-1.655)$
\end{tabular}

\begin{tabular}{lcccc}
\hline (2)Institutional pressure based on government evaluation ranking & & \\
\cline { 2 - 5 } & CRE1 & $C R E 1$ & CRE2 & CRE2 \\
& Model(1) & $\operatorname{Model}(2)$ & $\operatorname{Model}(1)$ & Model(2) \\
\cline { 2 - 5 }$I P_{-} R$ & 0.002 & $0.002^{*}$ & $0.014^{* * *}$ & $0.014^{* * *}$ \\
& $(1.440)$ & $(1.691)$ & $(4.728)$ & $(4.910)$ \\
$I P \_R * S O E$ & & $-0.070^{* *}$ & & -0.085 \\
& & $(-2.247)$ & & $(-1.126)$
\end{tabular}

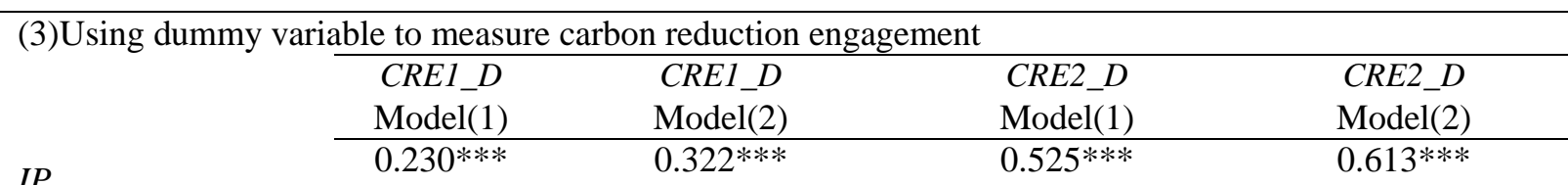

(2.603) (3.439) (5.130)

IP*SOE $-0.377 * * \quad-0.443 * *$

$(-2.316)$

$(-2.443)$

Panel C: Alternative sample-excluding NSOEs with political connections

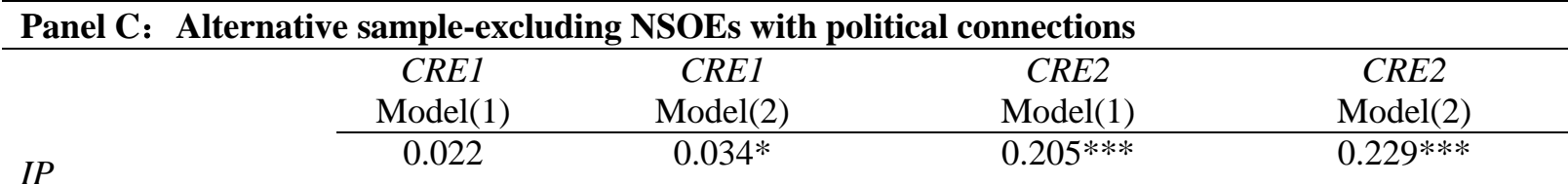

(1.486) (1.980) (3.015)

$I P * S O E$

$-0.095^{* *}$

$-0.195^{*}$

$(-2.193)$

$(-1.807)$

Note: Two-tailed robust z/t-statistics in parentheses are clustered at the industry level; *, **, and $* * *$ denote statistically significant at $0.10,0.05$, and 0.01 levels, respectively. Control variables, constant, and industry and year fixed effects are included in all the columns. For the sake of brevity, the table does not report the coefficients of control variables. 
Table 10 Effect of corporate carbon reduction engagement on firms' access to state-owned bank loans and government subsidies varying in SOEs and NSOEs: robustness checks

Panel A: Different measure of corporate carbon reduction engagement using dummy variable

\begin{tabular}{|c|c|c|c|c|c|c|c|c|}
\hline & $\begin{array}{l}\text { Loanstate } \\
\text { SOEs } \\
\text { Model(3) }\end{array}$ & $\begin{array}{l}\text { Loanstate } \\
\text { NSOEs } \\
\text { Model(3) }\end{array}$ & $\begin{array}{c}\text { Subsidy } \\
\text { SOEs } \\
\text { Model(4) }\end{array}$ & $\begin{array}{c}\text { Subsidy } \\
\text { NSOEs } \\
\text { Model(4) }\end{array}$ & $\begin{array}{l}\text { Loanstate } \\
\text { SOEs } \\
\text { Model }(3)\end{array}$ & $\begin{array}{l}\text { Loanstate } \\
\text { NSOEs } \\
\text { Model(3) }\end{array}$ & $\begin{array}{c}\text { Subsidy } \\
\text { SOEs } \\
\text { Model(4) }\end{array}$ & $\begin{array}{c}\text { Subsidy } \\
\text { NSOEs } \\
\text { Model(4) }\end{array}$ \\
\hline \multirow{2}{*}{ CRE1_D } & 0.059 & $0.244 * * *$ & 0.015 & 0.009 & & & & \\
\hline & $(0.78)$ & $(2.79)$ & $(0.70)$ & $(0.38)$ & & & & \\
\hline \multirow[t]{2}{*}{ CRE2_D } & & & & & -0.133 & $0.187 *$ & 0.010 & 0.038 \\
\hline & & & & & $(-1.25)$ & $(1.71)$ & $(0.34)$ & $(1.24)$ \\
\hline Diff. on $C R E$ & \multicolumn{2}{|c|}{2.63} & \multicolumn{2}{|c|}{0.03} & \multicolumn{2}{|c|}{$4.53 * *$} & \multicolumn{2}{|c|}{0.39} \\
\hline \multicolumn{9}{|c|}{ Panel B: Alternative sample size-excluding NSOEs with political connections } \\
\hline \multirow{3}{*}{ CRE1 } & $\begin{array}{l}\text { Loanstate } \\
\text { SOEs } \\
\text { Model(3) }\end{array}$ & $\begin{array}{l}\text { Loanstate } \\
\text { NSOEs } \\
\text { Model(3) }\end{array}$ & $\begin{array}{c}\text { Subsidy } \\
\text { SOEs } \\
\text { Model(4) }\end{array}$ & $\begin{array}{c}\text { Subsidy } \\
\text { NSOEs } \\
\text { Model(4) }\end{array}$ & $\begin{array}{l}\text { Loanstate } \\
\text { SOEs } \\
\text { Model(3) }\end{array}$ & $\begin{array}{l}\text { Loanstate } \\
\text { NSOEs } \\
\text { Model(3) }\end{array}$ & $\begin{array}{c}\text { Subsidy } \\
\text { SOEs } \\
\text { Model(4) }\end{array}$ & $\begin{array}{c}\text { Subsidy } \\
\text { NSOEs } \\
\text { Model(4) }\end{array}$ \\
\hline & 0.018 & $0.219 * *$ & 0.008 & 0.008 & & & & \\
\hline & $(0.40)$ & $(2.53)$ & $(0.65)$ & $(0.32)$ & & & & \\
\hline \multirow{2}{*}{ CRE2 } & & & & & -0.036 & $0.107 * * *$ & 0.002 & $0.017 *$ \\
\hline & & & & & $(-1.56)$ & $(3.12)$ & $(0.30)$ & $(1.87)$ \\
\hline Diff. on $C R E$ & \multicolumn{2}{|c|}{$4.09 * *$} & \multicolumn{2}{|c|}{0.00} & \multicolumn{2}{|c|}{$12.81 * * *$} & \multicolumn{2}{|c|}{1.35} \\
\hline
\end{tabular}

Note: Two-tailed robust $\mathrm{z} / \mathrm{t}$-statistics in parentheses are clustered at the industry level; *, **, and *** denote statistically significant at $0.10,0.05$, and 0.01 levels, respectively. Control variables, constant, and industry and year fixed effects are included in all the columns. For the sake of brevity, the table does not report the coefficients of control variables. 
Table 11 Effect of corporate carbon reduction engagement on firms' access to state-owned bank loans and government subsidies varying in SOEs and NSOEs (PSM)

\begin{tabular}{|c|c|c|c|c|c|c|c|c|}
\hline & $\begin{array}{l}\text { Loanstate } \\
\text { SOEs } \\
\text { Model(3) }\end{array}$ & $\begin{array}{c}\text { Loanstate } \\
\text { NSOEs } \\
\text { Model }(3) \\
\end{array}$ & $\begin{array}{c}\text { Subsidy } \\
\text { SOEs } \\
\text { Model(4) }\end{array}$ & $\begin{array}{c}\text { Subsidy } \\
\text { NSOEs } \\
\text { Model(4) }\end{array}$ & $\begin{array}{c}\text { Loanstate } \\
\text { SOEs } \\
\text { Model(3) }\end{array}$ & $\begin{array}{c}\text { Loanstate } \\
\text { NSOEs } \\
\text { Model(3) }\end{array}$ & $\begin{array}{c}\text { Subsidy } \\
\text { SOEs } \\
\text { Model(4) }\end{array}$ & $\begin{array}{c}\text { Subsidy } \\
\text { NSOEs } \\
\text { Model(4) }\end{array}$ \\
\hline \multirow[t]{2}{*}{ CRE1 } & 0.029 & $0.239 * * *$ & 0.012 & -0.019 & & & & \\
\hline & $(0.44)$ & $(2.90)$ & $(0.84)$ & $(-0.84)$ & & & & \\
\hline \multirow[t]{2}{*}{ CRE2 } & & & & & -0.021 & $0.049^{*}$ & -0.000 & $0.016 * *$ \\
\hline & & & & & $(-0.78)$ & (1.87) & $(-0.04)$ & (2.17) \\
\hline \multirow[t]{2}{*}{ Area } & 0.142 & 0.058 & 0.009 & $-0.061 *$ & $0.282 * *$ & 0.139 & 0.006 & -0.028 \\
\hline & (1.32) & $(0.49)$ & $(0.40)$ & $(-1.94)$ & $(2.44)$ & (1.23) & (0.19) & $(-0.85)$ \\
\hline \multirow[t]{2}{*}{$I N D D$} & 0.286 & -0.638 & 0.009 & $-1.010 * * *$ & 0.177 & 0.433 & $0.108 *$ & $-0.851 * * *$ \\
\hline & (1.22) & $(-0.90)$ & $(0.18)$ & $(-5.92)$ & $(0.74)$ & $(0.53)$ & (1.75) & $(-4.35)$ \\
\hline \multirow[t]{2}{*}{ BTM } & 0.024 & -0.068 & 0.011 & $0.075^{*}$ & -0.018 & -0.223 & -0.007 & -0.009 \\
\hline & $(0.27)$ & $(-0.43)$ & $(0.57)$ & (1.81) & $(-0.19)$ & $(-1.55)$ & $(-0.26)$ & $(-0.22)$ \\
\hline \multirow[t]{2}{*}{ Size } & -0.053 & $-0.157 *$ & -0.010 & -0.015 & -0.009 & 0.022 & $-0.039 * *$ & -0.014 \\
\hline & $(-0.77)$ & $(-1.95)$ & $(-0.63)$ & $(-0.72)$ & $(-0.12)$ & $(0.31)$ & $(-2.01)$ & $(-0.70)$ \\
\hline \multirow[t]{2}{*}{ Lev } & $1.236 * * *$ & $1.870 * * *$ & 0.000 & -0.050 & $1.364 * * *$ & $1.293 * * *$ & $0.271 * * *$ & 0.004 \\
\hline & (3.49) & (5.26) & $(0.00)$ & $(-0.53)$ & (3.74) & (3.92) & (2.90) & $(0.05)$ \\
\hline \multirow[t]{2}{*}{$R O A$} & -1.647 & -0.813 & 0.320 & 0.105 & -1.660 & $-3.667 * * *$ & $0.757 * *$ & $-0.622 *$ \\
\hline & $(-1.44)$ & $(-0.77)$ & (1.28) & $(0.37)$ & $(-1.23)$ & $(-3.05)$ & $(2.15)$ & $(-1.84)$ \\
\hline \multirow[t]{2}{*}{$F 1$} & 0.004 & -0.003 & 0.000 & -0.001 & 0.004 & -0.000 & -0.001 & 0.000 \\
\hline & (1.20) & $(-0.95)$ & $(0.12)$ & $(-0.57)$ & (0.95) & $(-0.13)$ & $(-1.02)$ & $(0.15)$ \\
\hline \multirow[t]{2}{*}{ TOA } & $-0.991 * * *$ & -0.435 & & & $-1.130 * * *$ & -0.449 & & \\
\hline & $(-2.84)$ & $(-1.33)$ & & & $(-3.29)$ & $(-1.41)$ & & \\
\hline \multirow[t]{2}{*}{$\mathrm{CFO}$} & $2.456^{*}$ & -0.812 & & & 1.534 & $-1.701 *$ & & \\
\hline & (1.87) & $(-0.89)$ & & & (1.10) & $(-1.85)$ & & \\
\hline \multirow[t]{2}{*}{ Age } & -0.006 & $-0.023 * *$ & & & 0.002 & -0.013 & & \\
\hline & $(-0.51)$ & $(-2.37)$ & & & $(0.18)$ & $(-1.47)$ & & \\
\hline \multirow[t]{2}{*}{ Htax } & & & 0.025 & 0.003 & & & $0.067 * *$ & 0.018 \\
\hline & & & $(0.92)$ & $(0.08)$ & & & (1.99) & $(0.50)$ \\
\hline \multirow[t]{2}{*}{$E T$} & & & 0.046 & -0.029 & & & 0.013 & -0.002 \\
\hline & & & (1.28) & $(-0.45)$ & & & $(0.28)$ & $(-0.04)$ \\
\hline \multirow[t]{2}{*}{ LSubsidy } & & & $0.431 * * *$ & $0.356 * * *$ & & & $0.428 * * *$ & $0.301 * * *$ \\
\hline & & & $(33.14)$ & $(17.40)$ & & & $(25.44)$ & (15.17) \\
\hline \multirow[t]{2}{*}{ Constant } & 1.671 & 2.097 & 0.141 & 0.426 & -0.254 & -0.852 & $0.979 * *$ & 0.395 \\
\hline & (1.05) & (1.16) & $(0.41)$ & $(0.94)$ & $(-0.15)$ & $(-0.55)$ & $(2.13)$ & $(0.90)$ \\
\hline Industry/Year & Yes & Yes & & & es & Yes & Yes & Yes \\
\hline Diff. on $C R E$ & \multicolumn{2}{|c|}{$4.18 * *$} & \multicolumn{2}{|c|}{1.84} & \multicolumn{2}{|c|}{$3.71^{*}$} & \multicolumn{2}{|c|}{2.41} \\
\hline Observations & 783 & 825 & 799 & 836 & 726 & 875 & 743 & 886 \\
\hline Pseudo/Adj. $\mathrm{R}^{2}$ & 0.076 & 0.086 & 0.641 & 0.349 & 0.076 & 0.073 & 0.140 & 0.243 \\
\hline
\end{tabular}

Note: Two-tailed robust $\mathrm{z} / \mathrm{t}$-statistics in parentheses are clustered at the industry level; *, **, and *** denote statistically significant at $0.10,0.05$, and 0.01 levels, respectively. 